Ilona RAUHALA (Helsinki)

\title{
The terms for black and white and their development in the Uralic languages
}

\begin{abstract}
This article deals with the colour terms for black and white in the Uralic languages, concentrating on their semantic development. Berlin and Kay (1969) suggest that all languages should have at least two basic colour terms: 'black' and 'white'. In the Uralic languages there is more than one old term for white, but the terms for black are rather young and etymologically unclear. The reason for this may lie in affect. In the Uralic data words denoting 'dirty' or 'unclear' may develop into a term for black. However, the denotation 'dark (of light)' does not seem to develop into a term for black. The old terms for white have the denotations 'bright' and 'pure, clean', but these denotations do not overlap without the denotation 'white'.
\end{abstract}

\section{Introduction}

Over the last few decades there has been lively discussion about naming colours in different languages. This discussion has been going on in both linguistics and anthropology, and it was initiated by the anthropologists Brent Berlin and Paul Kay (1969), who suggested an evolutionary system of the development of basic colour terms in language. In order to test Berlin and Kay's hypothesis, a data archive called the World Color Survey (WCS) was launched (<http://www.icsi.berkeley.edu/wcs/>). The WCS includes data on colour terms collected from the speakers of 110 different languages by means of the 330 Munsell colour chips, a colour chart used by Berlin and Kay and many fieldworkers since. This paper concerns colour terminology and the semantic development of the colour terms for black and white in the Uralic languages. I shall ask what semantic denotations may develop into a colour term 'black' or 'white'.

The human eye can distinguish hundreds of colours and shades in the spectrum (see e.g. Koski 1983: 35). However, the system of colour terms in a language is never anywhere near as vast as the eye's ability to distinguish between colours. Berlin and Kay introduced a restricted group of basic colour terms and named their referents "basic colours". Berlin and Kay defined a basic colour term as (a) monomorphemic (thus not, for example, ocean-blue), (b) not included in another colour term (e.g. scarlet is a kind of red) and (c) unrestricted in application to objects (e.g. brunette is only used to refer to hair) (Berlin \& Kay 1969: 6, also Croft 2003: 276). They discovered that the amount of basic colour terms varies in languages, as few as two or as many as eleven. Another discovery was that the foci of these basic colour terms are uniform across languages, i.e. the same hue was identified as the best exemplar of colour.

According to Berlin and Kay, all languages have at least two basic colour terms: a term for black and a term for white. According to the first version of Berlin and Kay's theory, the other colour terms emerge in the language in the following order (Berlin \& Kay 1969: 4): 
red $>$ green/yellow $>$ yellow/green $>$ blue $>$ purple, orange, grey (in free order)

This theory has been modified several times according to new evidence found in languages (see e.g. Levinson 2000; Croft 2003: 277, more closely discussed in Chapter 2.1 ), but the basic assumptions have remained the same: all languages have at least two basic colour terms, i.e. terms for black and white, and the next colour term emerging in a language is for red.

Many scholars have criticized the theory itself (e.g. Wierzbicka 2008), and also the method of defining the basic colour terms (e.g. Taylor 1991). Despite criticism the theory of Berlin and Kay is still used and the data in the WCS is compared to their theory (see e.g. Regier, Kay \& Khetarpal 2009).

Black and white are special in the colour chart as they are achromatic. Grey is also achromatic, but all other colours are chromatic. The achromatic colours refer only to brightness, not hue, but in languages with a two-term colour system, the colour terms for black and white refer to brightness as well as hue (MacLaury 1992: 161). William Croft (2003: 277) describes the conceptual space for basic colour terms with a diagram (Figure 1) which presents the division of colours into cool and warm and opposite pairs of hues. There has been a belief that the warm and cool categories are differentiated (Berlin, Kay \& Merrifield 1991). However, there are languages that have one common term for green and yellow, and even languages that have a common term for green-yellow-blue (ibid.). A connection between green, yellow and blue can be found also in the Uralic languages (PU piša 'gall; green, yellow' > MdE piže 'green; copper, brass; small, young; blue', NeT paderā $\chi \bar{a}$ 'gall-coloured, gall-like, yellow', UEW: 384-385).

This paper approaches the subject from an etymological and semantic point of view. The focus is on the terms for black and white, which, as Berlin and Kay assume, should be the terms found in all languages. Thus, it is plausible that the two terms were present also in Proto-Uralic. Etymologically however the case is not that simple. There is more than one term for white reconstructed in the Uralic and Finno-Ugric protolanguages (UEW), but no one term has been reconstructed for black. The term for black (musta) is the most common colour term by frequency in the vocabulary of Finnish (Saukkonen et al. 1979), and it is also the colour that is recognized most rap-

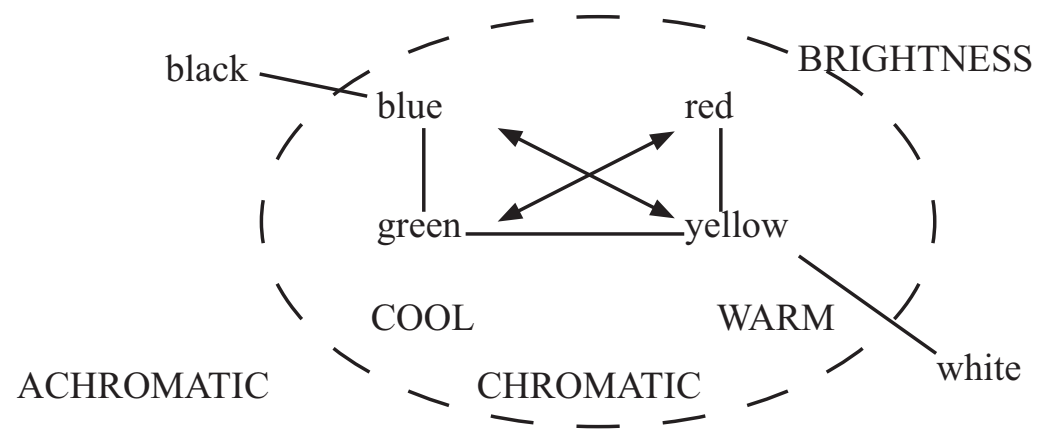

Figure I. Conceptual space for basic colour terms by Croft (2003: 277). 
idly of all colours (Taylor 1991: 12). For these reasons the term for black would have a good chance for being an old word. Nonetheless, none of the terms for black seem to be as old as the terms for white.

This study concentrates on the terms for black in the Uralic languages, their etymological background and the semantic extensions they have, and thus tries to find semantic fields in which the terms for black could emerge. I compare the data to Casson and Gardner's (1992; Casson 1997) notions on the semantic development of colour terms in English. He has studied the semantic development of colour terms from Old English to Modern English and found that the colour term system in Old English denoted brightness rather than hue. As the terms for black differ greatly in the Uralic languages, I have taken also the oldest Uralic terms for white, in which the patterns of semantic development can be seen and probably compared to the semantic development of the terms for black.

There is a fundamental difference between the data which Casson and I have used. The history of written English is much longer than the history of any written Uralic language, and its data set is large. The Uralic data, however, includes only modern Uralic languages, and thus assumptions of the semantic development of the colour terms must be based on the semantic extensions found in the modern languages. Also, Casson's focus is in the recent history of English, although he refers also to earlier phases of the language, i.e. the Germanic and Indo-European protolanguages. This study concentrates on the history of the colour terms for black and the oldest terms for white in the Uralic languages. However, this does not mean that the findings could not be compared. On the contrary, as Casson's data is broader, it is also rather reliable, and it does give hints as to what kind of denotations the colour terms may have and how these denotations may change.

The aim of this study is to determine what type of denotations terms for 'black' could develop from. In the present paper it is assumed that the colour terms for black and white in the Uralic languages may have developed from two separate semantic categories. The idea of colour has not been primary in these categories, but rather there were opposite pairs 'brightness/darkness' and 'cleanliness/dirtiness'. The hypothesis is motivated by an etymological approach to the semantics of the colour terms in the Uralic languages. In addition, the same division can be seen in the Germanic languages, where the German term for black, schwarz, is reconstructed in Proto-Indo-European as denoting 'dirty, dark, black' (Harper 2001-2011). The ancestor of the English term black is reconstructed as Proto-Indo-European *bhleg- 'burn, shine', which has in Proto-Germanic become *blakaz- 'burnt' ( $>$ Dutch blaken 'burn') (Watkins 1985: 6).

I will also present some notions concerning the question of why the terms for white are old and terms for black are not. The semantic extensions concerning the terms for black may help in this. If the affect towards the term for white is positive, there is no need to change the term. However, the colour black has taken on a negative affect in many parts of the world (Jäppinen 1999: 107), and such a negative affect is visible also in most Uralic languages. However, the colour black is not only connected to evil; take, for example, the English idiom in the black which refers to the condition 
of making profit (Merriam-Webster 1986: 90). Among the Saami people the blackcoloured reindeer is the most respected one (Lappalainen 1991: 23).

If the terms for black are connected with evil, as usually seems to be the case in modern western languages, this could be one reason to change the term from time to time (on word negation based on affect see e.g. Kulonen 2006: 324). It is possible that the neighbouring languages and their cultures have affected the Uralic peoples and their attitudes towards the colour black. It is also possible that there is no special need to change the colour term, but rather there is a case of a so-called luxury loan, i.e. a new word borrowed from another language even though a word with a similar meaning already exists. One example is Finnish hammas 'tooth' which was borrowed from Proto-Baltic even though the Uralic word pii 'tooth' was already present in the language. In this case the original word pii was preserved in a special meaning (a tooth of a rake), but sometimes the original word becomes extinct.

\section{Colour terms and their development}

\section{I. Discussion on colour terms}

The study of systems of basic colour terms is an example of research on lexical universals and diachronic typology in the lexicon. Berlin and Kay's theory of the evolution of basic colour terms has stimulated debate within linguistics and also anthropology (for criticism see e.g. Taylor 1991, Lucy 1997, Lyons 1999). Linguistically, Taylor (1991) has criticized the definition of "basic colour terms" and the way Berlin and Kay have excluded colour terms from their survey. On the other hand, John Lyons (1999) assumes that, based on his examples of the Austronesian language Hanunoó, culture has affected the development of colour terms, and that the cultural surroundings have much influence over the need for a colour term. John A. Lucy (1997) criticizes the entire method of collecting colour terms with the Munsell chips because it does not correspond to everyday life, as does Wierzbicka (2008) who maintains that there are languages that do not have a word denoting 'colour'.

The colour system has been seen as a division of colours into warm and cool categories, of which the terms for white, red and yellow belong to the warm category, while black, green, blue belong to the cool category (see Figure 1 in Chapter 1). However, there are systems that combine green and yellow, and they violate the principle of differentiating the warm and cool hues. This problem has been solved in later studies by assuming that colour terms are based not only on hues but also on brightness. This idea was brought forth by Robert E. MacLaury (1992), who has analysed both individual and cross-linguistic variation. He argues that already two-term systems containing terms only for black and white could be based on both brightness (light-dark) and hue (white-black) categories (MacLaury 1992: 161). MacLaury maintains that the category of colour began as a category of brightness, but the importance of hues has increased while the importance of brightness has decreased, and thus the focus of the colour terms has changed to hues. 
MacLaury's view is supported by Ronald W. Casson (1997) who has studied the development of colour terms in English. Casson compares the colour terms and their semantic development from Old English towards Middle and Modern English. He notes that in Old English the denotation of colour terms emphasized brightness, whereas towards Modern English the denotation has changed to hue.

John Lyons (1999: 53) has gone further in suggesting that the system of colour terms is not divided up only into hues and brightness, but also into dryness and wetness or freshness and desiccation. Of these, hue is the least relevant feature in naming colour. This assumption seems adequate as we observe what is important to peoples who have no need to define objects differing from each other only by colour. Casson has also recognized that the cultural surroundings affect changes in a system of colour terms. The brightness category changes towards hue when the colours become culturally significant (Casson 1997: 238). The languages studied are mostly spoken by peoples who live in a tropical environment. It is possible that peoples in tropical surroundings need slightly different colour terms than peoples living in northern areas and totally different weather conditions. However, none of the studies refer to this difference.

The Uralic languages have also been subjects of research into basic colour term systems. Probably the largest and most thorough study of the colour terms in Uralistics is Mauno Koski's study of basic colour terms in the Finnic languages (1983). Koski reaches the conclusion that the system of colour terms in the Finnic languages developed mainly after the Proto-Finnic stage. The only common Finnic colour terms are (in Finnish) valkea 'white', musta 'black' and sininen 'blue' (Koski 1983: 246). Koski suggests that Finnic sini 'blue' filled the black-blue category, but under the influence of Russian sinij 'dark blue' its denotation has moved to the blue-green area. He explains his suggestion by saying that the Finnic sini stem words refer to the same entities and verbs as the musta stem words, e.g. sinelmä, mustelma 'bruise' and the verbs si(i)ntää, mustottaa 'loom dark, loom in the distance' (1983: 248-249). As Finnic sini- has a cognate in Mordvin, E seń, M senem 'blue' (Turunen 2002: 177), Koski (1983: 248-249) suggests that in the Finnic-Volgaic protolanguage (if there was one) the term for light colours was *ačka and the term for dark colours *sine. Both terms have moved from their original foci in the colour chart, as Fi hahka denotes 'grey' and the derivates of *sine have 'blue' as their foci in both the Finnic and Mordvin languages.

Koski has excluded all terms for red from Proto-Finnic, because the Finnic languages have no common term for red. Koski's conclusion concerning the colour terms in Proto-Finnic does not take into account the possibility that a colour term could have replaced an older one in the case of the terms for red. Also István Futaky (1981) has studied the Finno-Ugric colour terms etymologically. He suggests one kind of colour system in Proto-Finno-Ugric, where he assumes that also a term for 'red' has existed in the Finno-Ugric protolanguage. I will comment Futaky's system later in this article.

Mari Uusküla (2008) has studied the basic colour terms in Finnish, Estonian, Hungarian and also Czech. She concluded that if there are two terms in a language denoting the same colour category, only one of them is basic (e.g. Hungarian piros 'red' and vörös '(blood) red', of which piros is a basic colour term, cf. Uusküla 2008: 11). She has also noted that the foci of a colour, i.e. the best examples representing 
certain colours, differ slightly from one language to another, although already Berlin and Kay (1969) assumed that the foci of a colour term are universal.

Also some individual Uralic languages have been studied according to their systems of colour terms: Mansi (Sipöcz 1994), Moksha Mordvin (Turunen 2002) and Estonian (Sutrop 1995, 2000). Common to all the studies concerning the colour terms in the Uralic languages is that they challenge Berlin and Kay's theory and/or the definition of a basic colour term that they make. Turunen compares the etymological background of the basic colour terms to Berlin and Kay's theory of the terms emerging in language. She concludes that the emergence of colour terms in the Mordvin languages does not follow Berlin and Kay's assumptions. However, the study does not take account the fact that colour terms tend to change just like any other words. It is always uncertain which colour terms have been replaced by other terms, and which terms are made for a "new" colour. Turunen also criticizes the criterion that young loanwords are not basic colour terms and she asks what a young loanword is exactly.

One of the latest studies is Johanna Parviainen's Master's Thesis (2010) in which she compares Finnish and Hungarian idioms that include colour terms. This study is more cultural than other studies mentioned above. In her study Parviainen found that the colour terms used most often in idioms both in Hungarian and Finnish refer to black and white.

\subsection{Semantic development and its patterns}

\subsection{Unidirectionality}

In this chapter I approach colour terms from an etymological point of view. There is a universal tendency that the meaning of a word develops from concrete to abstract (Futaky 1981: 53). Thus, a prototypical red thing such as blood may give its feature, colour, to a more abstract use: a blood-coloured car 'red car'. Like many other words in language, also adjectives are replaced by other adjectives. The patterns of semantic change seem to be similar: an old word is usually replaced with a new one taken from the same type of semantic environment as the previous one. For instance, in the FinnoUgric languages the word *puna originally denoted 'hair, fur'. In modern Finnish the denotation is 'red' (punainen), but the Erzya Mordvin cognate pona denotes 'colour' in addition to the original denotation 'hair; wool' (SSA 1995: 427). The same semantic change can be seen in the Finnish word karva whose primary meaning is 'hair, fur'. From this karva an adjective karvainen 'of some colour' has been derived, which is used in compounds like kullankarvainen 'of golden colour'. The semantic change is the same in both words:

'hair' > 'some specific colour, usually red or brown' > 'colour'

The development is unidirectional, i.e. it does not go backwards (Croft 2003: 252). 


\subsubsection{Prototypicality}

One naming motivation is prototypicality. Blood is red, and for example Hungarian has a word for red, vörös, which means literally 'bloody'. In English an orangecoloured fruit has given its typical feature to the colour term orange. Taylor (1991: 14) suggests that also the stability of colour focality noticed by Berlin and Kay as well as many others, has to do with the stability of certain attributes that are the prototypical referents of a certain colour.

For white, Ulla Jäppinen (1999: 65) assumes that the prototypical exemplar would be snow. However, the oldest Uralic words for white do not mean snow but light, sun and, in some cases, purity and cleanliness. Also in Jäppinen's examples only Latin niveus 'white, snowy' is a non-compound word that refers to both white and snow. In Finnish the word lumivalkoinen 'snowwhite' is commonly used, but it is a compound like German schneeweiss and English snowwhite. In Berlin and Kay's theory the basic colour terms must be monomorphemic, i.e. compounds are not accepted as basic colour terms.

The prototypical black entity in nature is coal. The prototypicality of coal as black can be seen in the Finnish compound sysimusta 'coal-black', which is an exact counterpart to lumivalkoinen 'snowwhite'. One could assume that the word for black might come from a word denoting 'coal', which in Proto-Uralic was *sü̈ße (> Fi sysi 'coal'). However, just as with terms for white, also the terms for black do not seem to have etymological connections to *śü $\delta$.

Ronald W. Casson has studied how the colour terms in English have changed from denoting brightness to denoting hues (1997: 224-239). He maintains that in Old English the colour terms denoted primarily brightness, but towards Middle and Modern English the denotation has mostly turned to hues. The English term black is descended from Proto-Indo-European (PIE) *bhleg- 'shine, flash, burn' ( ProtoGermanic *blakaz 'burned', Watkins 1985: 6). Old English blaec was a brightness term, but it had also a sense of hue: 'burnt, scorched'. Middle English blak was applied to the darkness of night and clouds, but more extensively to the hue of coal, soot; pigment and ink; hair, beard; cloth, clothing and mourning garb, etc. (Casson 1997: 227-228). The same semantic fields occur also in the data of the Uralic languages presented in Chapter 3.1.

There are four basic English colour terms reconstructed for Proto-IndoEuropean: white, black, red and yellow (Shields 1979). According to Casson (1997: 227), English has as many as seven basic colour terms that are etymologically of Proto-Indo-European origin. The case in the Uralic languages is totally different: most of the colour terms are borrowed from other languages, most recently e.g. Fi oranssi 'orange' < Eng orange. Colour terms tend to be borrowed even when the language already has a term for a certain colour, for example when Lude borrowed the term žoltii ‘yellow' from Russian жёлтый 'id.' even though it already had a word keldaine 'yellow' (Ojanen 1985: 70, 282). The reason for this kind of change may be communicative, i.e. the need to adjust the colour chart in Lude to match the one in Russian. 
Concerning the Finno-Ugric protolanguage (PFU), István Futaky (1981: 52) has studied the colour terms that could be reconstructed for PFU and suggests a threecolour system which is presented in Figure 2.

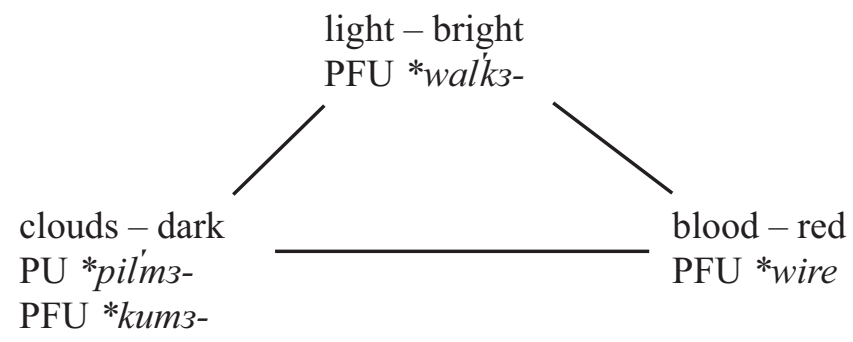

Figure 2.The Finno-Ugric basic colours according to Futaky (I 98I).

The system Futaky presents is close to MacLaury and Casson's idea of a brightness category. It does not merge the difference between brightness and hue, as can be seen in the semantic fields presented in the chart. Futaky's colour term system is based on prototypicality, and the bottom line of his reconstruction is Berlin and Kay's theory of the development of colour terms. He selects the words that, by his assumptions, could semantically be colour terms in Proto-Uralic, and he concludes that a probable candidate for white is PFU *wal-kз- (> e.g. Fi valkea 'white, light, shiny; shine, light') while candidates for black are PFU *kum3- (> MdE kovol 'cloud', Ko kimer 'cloud', Hu homály 'dim, dimness; darkness (of light)' (UEW: 204) and Proto-Uralic *pil'm3'dark (of light)' (> e.g. Fi pimeä 'id.', see e.g. Janhunen 1981). However, neither of the words that Futaky suggests for the semantic field 'dark' or 'black' have the denotation 'black' or any other colour in the present-day Uralic languages. The former denotes 'cloud' and 'darkness (of light)', and the latter 'dark (of light)' (SSA 1995: 367). This is something fundamentally different from e.g. English and German, where Eng dark and Ger dunkel denote both darkness of light and of colour. The English term dark comes from Proto-Germanic *derkaz (> Old English deorc 'dark, obscure, gloomy; sad, cheerless; sinister, wicked'), the original denotation of which was 'absence of light', especially at night. The denotation of colour emerged as late as the 16th century (Harper 2001-2011). In some dialects of Estonian the word pime means also darkness of colour (Oja 1999: 196). However, this denotation occurs in dialects that are close to the borders of Estonia and thus one may assume that the denotation of the darkness of colour has been influenced by neighbouring languages, e.g. German which has had a great impact on Estonian.

Based on MacLaury and Casson's notions of colours dividing into categories of brightness and of hue, I suggest that in the Finno-Ugric protolanguage there were two, probably simultaneous systems, one referring to brightness (Figure 3 ) and the other to the opposite pairs of cleanliness and dirtiness, and also hues (Figure 4). 


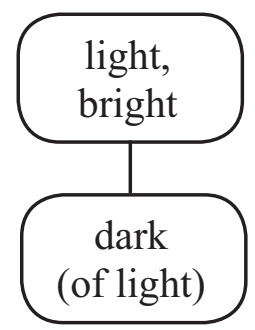

Figure 3. Opposite pair in the category brightness.

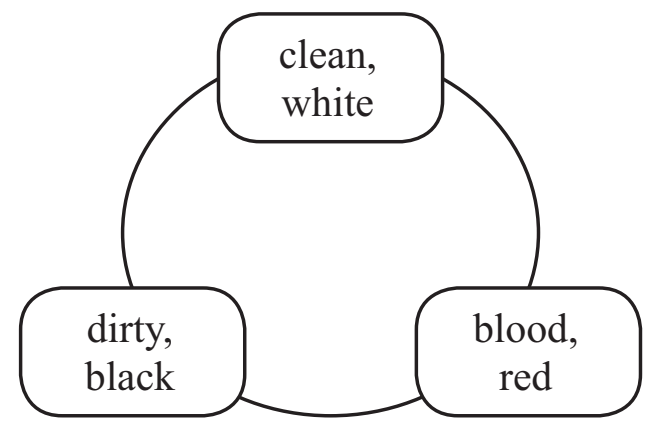

Figure 4.The opposite pair 'dirty'-'clean' and hue.

The reason to place other colour terms in the same figure with the field dirtinesscleanliness is based on Casson's system of two categories, one brightness and the other hue. Also Latin, which has fewer colour terms than Modern English, has two terms each for black and white; ater 'black', niger 'shiny black', albus 'white', candidus 'brilliant, bright white' (Taylor 1991: 4).

Casson maintains that the entire colour system has changed from brightness to hues, and thus he does not present a simultaneous two-category system as I do here. According to Casson, many of the chromatic colours have referred also to some state of brightness, for example red which was a hue-dominated term but denoted also luminosity and reflectivity, e.g. flames, fire, lightning, dawn and also gold and swordedges (Casson \& Gardner 1992: 396). Although I present here two systems as simultaneous, they are not necessarily so. The categories can be seen as semantic motivations where the terms for black and white have developed.

Both systems presented above are expected to develop colour terms, but it is uncertain whether the categories can overlap. The answer can be sought by monitoring the semantic extensions that the different terms for black and white have, and this is what I shall do in the next chapter.

\section{Etymological explanations and semantic motives in the terms for 'black' in the Uralic languages}

The following presents etymological data given for the terms for 'black' in the Uralic languages. The words are collected from dictionaries, both synchronic and etymological. In addition, some examples of use collected from text samples, studies and chrestomathies are provided.

Some dictionaries contain more than one word for 'black' and it is not always easy to define which is the basic colour term. Many of the dictionaries give examples of usage, e.g. verbs and compounds, which makes it easier to define what words might 
be the basic colour terms. The examples of usage help also to define the additional denotations, although usually they are too few to show how widely used they are. However, in some instances the examples are few and it is unclear what types of use the word has. Especially problematic is the translation dark (German dunkel 'dark') as it refers to both darkness of light and colour. However, usually the examples refer only to the darkness of colour. The Uralic data displays a division between darkness of light and colour. In some cases also informants have helped with this problem of translation.

The words are presented in separate articles, but etymologically related words are discussed together in a single article, e.g. the term for black in Mansi, sēmel, is presented together with the Mari term šem because of the possible etymological connection they have.

\section{I. Data}

\section{I.I. Finnic *musta}

PFi * musta 'black; dirty' > Fi musta 'black', Ing musta 'black, dark (colour); dirty', Ka musta 'black, dark (colour); dark (of light); dirty', Lu must(e) 'id.', muzed 'dark (of colour), blackish', Ve must 'black', muza 'dark (of colour)', darkish, Vo mussa, Est must 'black; dirty', Li mustā 'black; dirty' (SSA 1995: 183; Koski 1983: 59-63; Zaiceva 2010: 261)

$=$ PSaa *moste- $>$ SaaN mosttas 'thick, cloudy, muddy, not clear (of fish-oil and boiled fat)' (Koivulehto 2001: 71, Nielsen 1979: 690), SaaS måstodh 'take fright, get wild (of driving reindeer)', SaaLu måstōs 'heavy, depressed (of head); angry', SaaIn mostos 'dark (of colour)', SaaSko mõsttad 'stick; get dirty (vessel, cloth), become black' (Bergsland \& Magga 1993: 199; LuLpW: 560; InLpW 1987: 156; T. I. Itkonen 1958: 897)

<* PGerm *mus-ta- > Nr must 'steam, fog' (Koivulehto 2001: 71)

The common term for 'black' in the Finnic languages is *musta: Fi musta, Ing musta, Ka musta, Lu, Ve, Est must, Li mustā (Koski 1983: 59-63). It has parallel variants musea, museva 'dark (of colour), blackish' (SSA 1995: 183; Koski 1983: 59-63) and in some Veps dialects musket (Koski 1983: 59-63; Mullonen \& Zaiceva 1971: 339). Veps has also a word muza that does not denote 'black' but 'dark (of colour)' (Zaiceva 2010: 261). The Finnish and Karelian variants musea (Ka musie) and museva (in Karelian also the forms musava, musova) do not denote exactly 'black' but rather moderate 'blackish, dark'. In Lude and Veps the word muzav has also denotations '(dark) brown' and 'dark grey'.

In addition to referring to the colour 'black' (in Ingrian and Karelian also 'dark (colour)'), the Finnish term musta and its cognates in the other Finnic languages denote 'dirty' (SSA 1995: 183, see further different meanings in Koski 1983). Koski 
assumes that the denotation of dirtiness might be borrowed from German, Latvian and some dialects of Russian. One must consider the possibility that the denotation 'dirty' may be older than the denotation 'black'.

The denotations common to all Finnic languages are 'black' and 'dirty'. In some Finnic languages such as Ingrian, the derivates of Proto-Finnic *musta mean also a dark colour. In Karelian and dialects of Finnish the colour term for black means also lack of light. Koski (1983: 62) assumes that in many languages the term for black may have a secondary metaphorical denotation of darkness (lack of light), especially when referring to night (also Jäppinen 1999: 111). In Karelian the denotation 'dark (of light)' has been lexicalized:

nämä on mussat päivät, ei soa ńi midä ommella

These be.Prs.3 black.PL day.PL NEG.SG3 can.NEg nothing sew.INF

'These are black days, one cannot see to sew anything' (Koski 1983: 62; KKS

1983: 381).

However, the secondary nature of the meaning 'dark (of light)' is still visible, as the informants have tended to add the word pimie 'dark (of light)' to explain what they mean: mustad päiväd, pimied 'black days, dark (ones)' (Koski 1983: 62).

It has been assumed that the word museva was borrowed into Saami: SaLu måsså 'grey or white-grey reindeer', måsåk 'yellow (of a dog); grey (of a reindeer), måskå 'hoary (of reindeer)', SaaN mosat 'greyish reindeer' (SKES 1958: 353; SSA 1995: 183). However, this assumption is not phonologically or semantically correct. Instead, the SaaN word muzet 'brownish-black reindeer' is probably borrowed from Finnic, as presented in SKES.

Thus far, the most probable etymology for Finnish musta has been given by Jorma Koivulehto (2001: 71), who connected it with the SaaN mosttas 'thick, cloudy, muddy, not clear (of fish-oil and boiled fat)'. He suggests a Germanic origin for the Finno-Saamic word: Proto-Germanic *mus-ta- > e.g. Norwegian must 'steam, fog' (ibid.). Häkkinen (2004: 745) explains the semantic connection by saying that in weather conditions fogginess is understood as dark or gloomy.

The word mosttas is not included in Juhani Lehtiranta's list of words common to the Saami languages (1989). However, the word seems have the following cognates in other Saami languages: T. I. Itkonen (1958: 24) has connected North Saami mosttas to the Skolt mõsttad 'stick; become dirty (vessel, cloth), become black' and Inari Saami mostos 'dark', mostod 'lose its colour, bleach, become darker (clothing), lose the silvering'. Lagercrantz (1939: 493) has suggested a cognate in Lule Saami måstōs 'heavy, depressed (of the feeling in the head); angry', måstōtit 'cook so heavily that the soup fat mixes with the bouillon'. In addition, the South Saami verb måstodh 'take fright, get wild (of driving reindeer)' is probably cognate with SaaN mosttas, although it is semantically more abstract than its cognates. Phonologically this comparison is unproblematic. Semantically it is valid if we assume that the present-day form originates from the denotation 'stirred, fuzzy', as in SaLLu måstōs 'heavy, depressed; 
a bit angry'. According to the words presented above, the Proto-Saami reconstruction would be *moste- which, in principle, can be cognate with Proto-Finnic *musta. The Saami branch has mostly the denotation 'unclear, thick, stirred', whereas in the Finnic languages the common denotation is 'black; dirty'. The denotations of 'black' and 'dirty' in Skolt and Inari Saami may be borrowed from Finnic, or they may be an inner development such as the Old English salu 'sallow' (> Eng sallow) that had sense of brightness 'dark, dusky' and sense of hue 'dirty, discoloured' (Casson \& Gardner 1992: 395).

Koivulehto connects also the Saami adjective moskkus 'cloudy' (<PSaa *moskē, Lehtiranta 1989: 76-77; Koivulehto 2001: 71) to the words listed above, and argues that in Proto-Germanic there was a parallel form *mus-ka- (> Icel mosk 'dust', $\mathrm{Nr}$ musk 'dust, dust clouds, cloudiness, darkness, sprinkle', Swiz muschen 'smudge', also Nr svart-musken 'very dark', Koivulehto 2001: 71). Concerning the borrowing of the given word it must be noted that, in fact, the latter stem corresponds oneto-one with Veps musket 'black'. Koivulehto does not explain the rise of the other derivational types represented in Fi, Ka museva, Ly muzed that have no word-internal $-t$ - or $-k$ - However, due to both semantic and formal similarities, they clearly belong together with Ve musket and Fi musta. Valmen Hallap (1983) notes that in the Finnic languages, the derivational suffixes $-e A$ and $-k e A$ display ample variation, and they may be mutually replaced without semantic change, as in the Finnish adjectives vire $\ddot{a}$ 'lively, sprite' and virkeä 'id.'.

In short, Proto-Finnic *musta and Proto-Saami *moste- are cognates, and they are borrowed from Proto-Germanic *mus-ta. Koivulehto suggests that Saami *moske (> e.g. SaaN moskkus 'cloudy') may be borrowed from Proto-Germanic *mus-ka (> e.g. Nr musk 'dust, dust clouds, cloudiness, darkness, sprinkle') that is a parallel form for *mus-ta. If this suggestion is correct, then also Veps musket 'black' could be borrowed from Proto-Germanic. The forms musea, museva can be explained as analogical forms. The phonological variation can be explained so that the words musta and Veps musket needed a "basic" form and thus the words museva, musea were formed to fulfil the suffixal analogy. The Veps form muza 'dark (of colour)' could also be explained by analogy, which means that muza does not need to be the form from which muzed is borrowed. However, the possibility must also be considered that muza could be original, and then Koivulehto's etymology would be more difficult to maintain.

The original Germanic meaning of Proto-Finnic *musta and Proto-Saami *moste- has naturally left traces in the semantic extensions of the word. Dirtiness and murkiness are primary meanings in Saami, where the semantic development has not lead to a colour term. Also in the Finnic term, where the common primary denotation is 'black', the earlier denotations are still visible. Koski has assumed that the denotation of dirtiness in Finnic is borrowed from the neighbouring languages. Koivulehto's etymology removes the need to assume a semantic loan because dust is also dirty and thus the semantic development towards 'dirty' can be expected. 


\section{I.2. Saamic *'́āppe}

PSaa *'́āppe 'black' > SaaS tjeehpes 'black', SaaU tjaahpada, SaaPi tjaah 'pat 'id.', SaaLu tjahppat 'black; dark (colour); altogether, utterly', SaaN čáhppat 'black; dark; (in certain phrases) quite empty, quite without; altogether, utterly', SaaIn čappad 'black', SaaSko čappâd 'black', SaaKld čoahpes 'black, dark' (Lehtiranta 1989: 22-23; Bergsland \& Magga 1993: 306, 312; LuLpW: 1136; Nielsen 1979: 366-367; InLpW 1986: 71; T. I. Itkonen 1958: 646; Kuruč 1985: 397)

The Saami languages have a common term for black, PSaa *ćappe 'black', but the etymology beyond Proto-Saami is yet unknown. The semantic extensions of this colour term denote neither dirtiness nor darkness (of light). Instead, emptiness and invisibility is something very typical to at least the North Saami čáhppat. It can be seen also in the verb čáhpodit 'become black; become quite black; disappear'. The denotation of disappearance can be found also in an Inari Saami idiom, which, however, may also be borrowed from North Saami Čáhpo nu! 'Get lost' (example from Idström \& Morottaja 2006: 13):

\section{Te koolgah čápudiđ̋! \\ PRT must.sG2 become.black.INF \\ 'Get lost!'}

The adjective čáhppat is used also of a sea or a lake that has no fish in it (Sammallahti 1989: 77), and probably also the North Saami idiom čáhppes geafi 'poverty-struck' has the idea of emptiness behind it. This same idiom is known also in Lule Saami. Many other Uralic languages, such as Finnish mustottaa 'loom, be visible in the distance' and Erzya Mordvin rauždoms 'loom black, start to shine black' have at least some kind of idea of being visible, not invisible as in (North and Lule) Saami. It is possible that the idea of murkiness has caused a development towards invisibility. The additional meanings to the terms for 'black' in Saami are highly negative; e.g. SaaIn čappadas 'devil', Lu tjāhputit 'be black; (fig.) be bad, evil, godless'. Also in other Uralic languages such as Moksha Mordvin (see next chapter) the negative aspect is visible.

Some attempts have been made to identify cognates to Saami *ćappe, but they have been rejected mostly because of phonological difficulties. For instance, Wiklund (1894: 117) has connected SaaN čáhppat with Fi häpeä 'shame', but this comparison is not valid due to the initial consonant: Saami $\check{c}$ - does not correspond to Finnish $h$ Instead, the correspondence of SaaN $\check{c}$ - should be $s$ - in Finnish. The denotations referring to emptiness and somewhat total loss are unique when compared to other Uralic languages. Although these denotations may be a later development from the colour term, it must be considered that these special denotations could be even older than the colour term itself. 


\section{I.3. Mordvin ravužo, ravuža}

PMd *ravâ- > E ravužo, raužo 'black, dark; dirty', (dial.) raužosto 'dirty', M ravuža 'black, dark; dirty; (dial.) devil; black clothes, mourning garb' (MdWb 1994: 1887-1888)

? = Fi rapa 'mud; mire; gravel, rubble; fragile, crispy', Ka raba(h)ine 'muddy', Est raba 'marsh'

In the Mordvin languages the term for black is E ravužo, M ravuža. In Mordvin, as also in Finnic, the term has the additional denotation 'dirty'. In some dialects it also has the denotation 'devil' (MdWb 1994: 1887-1888), but otherwise the denotations are much the same as in the Finnic languages. In some dialects of Moksha the word denotes also 'mourning clothes'. However, this denotation may be borrowed, as in European cultures the colour of mourning is black (Jäppinen 1999: 107). The verbs derived from ravužo refer to looming and being dirty, just like the Finnish verb mustottaa 'loom dark, loom in the distance': rauždoms 'shine black, begin to shine black', rauškadoms 'black; begin to shine black; be dirty' (MdWb 1994: 1887-1888). The translational problem is the denotation 'dark'. According to an Erzya informant, the word refers mainly to the darkness of colour, but metaphorically it can be used for light, e.g. meneleś raužkads' 'the sky darkened'.

The following riddle is an example of the use of colour terms in Erzya Mordvin:

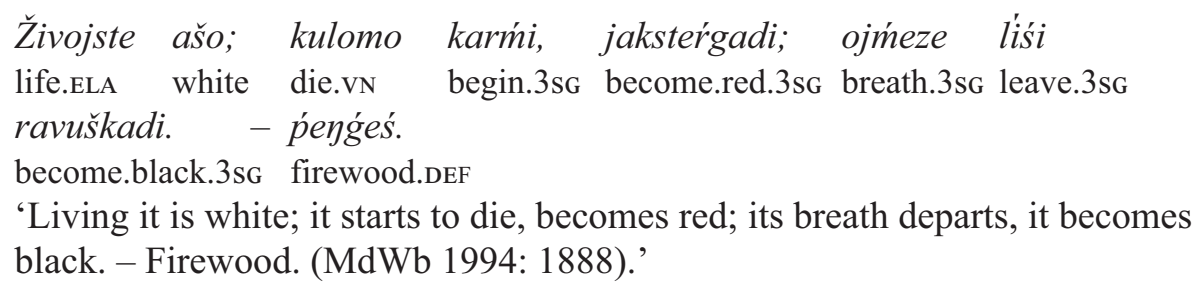

In this riddle we can see that sometimes it is hard to divide brightness from hue, especially when it comes to the word "white'. Is it a coincidence that these three "first" basic colour terms occur in a riddle that refers to an ancient entity: burning wood? The first stage of the firewood in the riddle refers probably to the white growing birch, which is the best type of firewood.

The origin of this colour term is thus far unknown. Structurally, a three-syllable word is presumably a derivation. Turunen (2002) has noted that the Mordvin ending $\mathrm{E}-\check{z} a, \mathrm{M}-\check{z} o$ occurs in many colour terms. She explains that many colour terms have had the same ending in the first place (piže 'green', ožo 'yellow'), and so this ending has been connected with colour terms and consequently e.g. ravužo has been formed by using the $-\check{z} V$ as a suffix. In Mordvin there is a moderative adjective suffix -ža, for instance E bérán 'bad' $\rightarrow$ béraža, E piže 'green' $\rightarrow$ pižeža (Bartens 1999: 109; Serebrennikov 1967: 77), and it may have been used in forming a new adjective from a stem * ravâ. There is only one word that looks similar to the stem and it is the 
name of the river Volga: rav, rava (MdWb 1994: 1887-1888). Support for a connection between the colour term and the name of the river is the idiom Mon rauškadin rav(-)lopaks. 'I was as black as the Volga-leaf'. This connection may be etymological, phonological (rhyme) or metaphorical (the blackened leaves in the Volga River).

The colour black is usually a very typical appellative in place names, but according to Rahkonen (2009: 178) there are no Mordvin place names formed with ravužo, ravuža. Instead, Rahkonen (ibid.) notes that the term used in Erzya Mordvin place names is čem-, which is probably identical with Mari šeme 'black'.

The Mordvin stem ravu- could be cognate with Finnish rapa 'mud, mire; gravel, rubble; fragile, crisp' (Janne Saarikivi, p.c.). The SSA (2000: 49) suggests that Finnish rapa 'mud, mire; gravel, rubble; fragile, crispy' is of the same "onomatopoeicdescriptive" origin as rapea 'fragile; crispy'. The assumption of an onomatopoeicdescriptive origin is probably based on a connection with the verb rapista 'rustle; fall'. Descriptive or onomatopoeic-descriptive explanations are very typical in the SSA, although descriptiveness or sound symbolism is rarely valid as an etymological explanation (see e.g. Saarikivi 2006, Aikio 2009).

Semantically Finnish rapa and Mordvin ra(v)užo could fit together, because the semantic shift between 'black' and 'dirty' seems possible in e.g. Finnic languages as demonstrated above (in Chapter 3.1.1), and it is present also in the Mordvin languages. A parallel example is German schwarz 'black' which means also 'dirty' and comes from Proto-Germanic *swartaz 'black', in turn from PIE *swordo- 'dirty, dark, black' (Harper 2001-2011).

\section{I.4. Mari šem(e)}

PMa *šims > H šem(e) 'black; dirty; black(blood), brown (of skin)', šemalye 'dark (of colour)', M šimi 'black' (TschWb: 671)

Either = Fi häme: mennä hämeeseen 'get sour, spoiled (of soup)', hämen 'the first wool from a sheep', ?? hämärä 'dim', EstS hämm(e) 'damp, wet', ? Md E čem: čemeń, M šämeń 'rust; (dial.) mould that spoils corn' (Koponen 2009) $<\mathrm{PU} * \check{s} 3 m_{3}$

Or = ManN E sēmèl, W šèmèl, S š̄̌mèl ‘black' (Lytkin 1970: 258) < PFU *śsm3

Mari šem(e) is semantically somewhat identical to Finnish musta. In addition, blood can be described with šem(e), as well as the brown colour of skin (TschWb: 671). There is a verb šememeš 'the sky gets dark'.

The etymology of this term is still unknown, but it has been compared to various Uralic words such as Finnish hämä-, hämärä 'dim' (e.g. Setälä 1899: 267; Lytkin 1970: 258). This assumption has been rejected (SSA 1992: 208), but the question of possible cognates for Finnish hämä- is still being discussed (e.g. Koponen 2009).

Lytkin (1970: 258) compares Mari šem to Komi sim 'rust, rusty; dark (colour)', a term which occurs also in compounds like simgerd 'dark red' and derivatives like simid 
(Udora dialect) 'cloudy (of weather)'. Komi sim and Mari šem are compared also to Mansi sēmèl, dial. šemèl 'black'. Lytkin has assumed Mansi K simil 'rust' to be a variant of the word sèmèl, but according to the dictionary of Munkácsi and Kálmán (1986: 547) they are separate words, and the one with the meaning 'rust, rusty' is a loanword from Komi (also Rédei 1970: 150). In addition, Komi sim does not belong together with the words suggested by Lytkin for phonological reasons. The Komi initial sibilant $s$ - should go back to ${ }^{*} s$, not $*_{s}^{\prime}$ as in Mansi, or $*_{s}$ as in Finnish hämä-. In Mari the three sibilants have merged, and thus initial $\breve{s}$ - can be traced back to $*_{S},{ }^{*} \dot{s}$ or $*_{\breve{s}}$.

To the same word group Lytkin adds also Mordvin E čem-: čemeń, M šämeń 'rust' and Hungarian szenny 'dirt' (Lytkin 1970: 258). In later studies Hungarian szenny and the adjective szennyes 'dirty' have been compared to Hu szén 'coal' and it is thought probable that szenny and szennyes are irregular derivates from this (Zaicz 2006: 787).

Mordvin čem- 'rust' could phonologically be cognate with Mari šem, but semantically the comparison is problematic. This čem-occurs in hydronyms, whereas the expected ravužo 'black' does not (Rahkonen 2009: 178). It seems that in hydronyms the naming motivation would have been black, as in Mari šem. If the original meaning of Mordvin čem- was 'black' and the denotation 'rust' were a semantic loan from e.g. Komi, the comparison would be unproblematic.

For Mordvin čem- there is an additional meaning 'mould that spoils corn' in MdWb (1994: 235). Koponen (2009) has suggested that the Finnish word häme in mennä hämeeseen 'get sour, spoiled (of soup)' and South Estonian hämm(e) 'damp, wet' are cognates with Md čem. The comparison is both phonologically and semantically valid, and Mari šem 'black' could be a cognate because the semantic development from 'unclear' to 'black' has occurred also in Finnish musta 'black', of which the Proto-Saami cognate *moste 'unclear' is parallel to the semantic development in Mari versus Mordvin and Finnic.

It is unclear, whether Finnish hämärä 'dim' is etymologically of the same origin as the häme that refers to mould or some other substance that spoils food. The SSA (1992: 208) includes häme under a word hämätä 'bamboozle; confuse; amaze' with a comment that also the words hämärä and hämmentää belong to the same descriptivetype group. Also Koponen (1998: 514) has suggested a descriptive group $h V m(m)$-, in which he later includes also Mari šem and Mordvin čemen (Koponen 2009). The word group he suggests is too vast and too heterogeneous to be reliable.

Also the ethnonym Häme 'a province in Western Finland', hämäläinen 'a person living in Häme' has been connected to the Finnish hämärä from time to time (e.g. Koivulehto 1997), but the connection is still uncertain. Koivulehto has suggested that all these words - häme 'ethnonym for western Finland', hämärä 'dim', hämmentää 'stir; confuse; embarrass', and possibly also häme in mennä hämeeseen 'get sour, spoiled (of food)' - belong together and derive from Proto-Germanic *sāma- 'dark (of human); dim, cloudy' (Koivulehto 1998: 429). If this is the case, the Finnish words häme, hämärä cannot be cognates with Mari šem 'black'.

Mari šem is not a cognate of Komi sim, but it is probable that it is related either to Finnish häme or Mansi sēmel 'black'. Both options are not possible because 
Finnish hämä- should go back to Proto-Uralic *šsmз while Mansi sēmèl goes back to PU *śsm3. The fact that the sibilants $s$ and $\breve{s}$ occur in different dialects of Mansi suggests an ancient origin (Honti 1986: 260) and thus supports the assumption that this word should have relatives also in other Uralic languages.

\section{I.5. Permic *śód}

PPerm *śod > Ko śed 'black; dirty; target (in shooting)', Udm śéd, śod, śed 'black, dark (of colour); (dial.) dirty' (Csúcs 2005: 378; Wichmann \& Uotila 1942: 246; Wichmann 1987: 232)

? = Fi sonta 'muck, dung', Ma šandâ, šondâ 'muck, dung; urine' (Wichmann 1954: 103)

In the Permic languages the term for 'black' is in Komi and dialects of Udmurt śed. The translations do not distinguish between darkness of light and colour. However, in derivatives the denotation seems to be 'dirty' rather than 'dark (of light)', as can be seen in Ko śedamni 'be black or dirty', śedaśni 'become or get dirty; (?) shine black' (Wichmann \& Uotila 1942: 246). An interview with an Udmurt informant confirmed that Udm śed does not refer to darkness of light, only of colour.

The Proto-Uralic ancestor of Permic śed would be reconstructed as *śsnts or *śsmt3. Wichmann (1954:103) has connected the Permic words with Finnish sonta 'muck, dung', which is cognate with Mari šandâ, šondà 'muck, dung, Abtritt, urine' (E. Itkonen 1953: 163, SSA 2000: 199). Phonologically Wichmann's comparison is unproblematic, but in UEW (764-765) this etymology has been rejected due to semantic differences, as also in SSA. However, already earlier in this chapter we have seen that the semantic development from 'dirt' to 'black' is more regular than exceptional in the Uralic languages, and therefore I see no reason to discard Wichmann's etymology.

\section{I.6. Ugric *pükkз-ttз}

$>$ Kha piti, N (dial.) payt3 'black; bear meat; N (dial. also) '(dark) blue', Hu fekete 'black; dark (of colour); fig. dark (of light); black coffee' (Zaicz 2006: 205)

Man pit, piti 'black; bear; dark (of light)' (Sipöcz 1994: 54) < Kha piti, payt3 (Munkácsi \& Kálmán 1986: 444a)

The Ugric languages have a common term for black that has no denotation of dirtiness. The Ugric languages have one common term for 'black': Khanty piti, poyt3 (Paasonen \& Donner 1926: 176), Mansi pit, piti, and Hu fekete (Zaicz 2006: 205). Mansi pit, piti has probably been borrowed from Khanty (Munkácsi \& Kálmán 1986: 444a), and according to Sipócz (1994: 103), the semantic field of use is more restricted than that of sēmal 'black'. 
This term does not seem to have undergone a semantic extension to 'dirty', but it does have a denotation 'dark (of light)'. The extension may be secondary, as in Hungarian it is used figuratively. This seems to be the case in the Finnic languages. Interestingly, Khanty piti has also the denotation 'bear meat'. Unfortunately the dictionaries of Khanty do not give examples of the word's use in this denotation, and thus also the reasons to refer to meat with the term for black remain unknown. It may refer to the edibility of the meat just as musta liha 'black meat' in Finnish. Another possibility is that it is an euphemism because of the taboo nature of words referring to the bear, a rather common phenomenon in the Uralic languages. The Khanty term refers also to evil, as it is used in payta wenčap 'devil' (DEWOS: 1135; KT: 682), literally "black-foreheaded". It occurs also in pəytə jəyk, literally "black water" denoting 'spirits' (ibid.), although the colour of the liquor is definitely not black.

The compounds presented in e.g. Khanty are names for animals and denote colour, e.g. paytəkərəp 'black woodpecker' (Paasonen 1926: 176). In Mansi it is used in compounds denoting darkness in a colour: pittēlp 'bled blood, dark red' (Sipőcz 1994: 54). Also some kind of evil is present in pittöram 'underworld' (ibid.), which is parallel with North Saami čáhppesáibmu 'underworld', literally "black-air".

Johanna Parviainen (2010) has studied Finnish and Hungarian idioms that include a colour term. She presents an idiom A fekete bika (a) lábujjára hágott 'a black ox trod on the toe', which refers to death. Here, the colour black is a symbol of death. The idiom seems typical for Hungarian, but it does not exist in Finnish (Parviainen 2010: 61). Many idioms in Hungarian have been borrowed from German, e.g. fekete könyv < Ger Schwarzbuch 'black book or list' (Zaicz 2006: 205), and it is possible that German has idioms referring to the black ox as a symbol of death. Thus far I have not been able to find any, which suggests that the Hungarian idiom may be original or borrowed from some language other than German.

One idiom in Parviainen's data refers to dirtiness (Parviainen 2010: 66): fekete tehénnek is fehér a teje 'The black cow's milk (is) also white'. It means that the income one gets from dirty work is equal to the income of anyone else. Parviainen suggests that the colour black in this idiom refers to the dirtiness of the work one does, while fehér 'white' refers to the good and honest income.

Parviainen (2010: 76) concludes that the Hungarian idioms with fekete have negative denotations. They refer to dirt, evil, illegality and also death. However, many of the idioms are borrowed from other languages, and thus the reliability of original denotations is small. Especially fekete referring to dirtiness is rather unclear, as the idiom presented above is rather abstract and it is difficult to determine what kind of dirtiness lies behind this idiom.

There are a few possibilities for reconstructing a Proto-Ugric form: *pöktз, *p or *pökks-tt3, depending on which language is the starting point. The latest etymological dictionary of Hungarian uses the form *pökk3-tt3 (Zaicz 2006: 205) and assumes that *-tt3 is a denominal derivational suffix. Thus the Ugric stem would be *pökks, although it is rather strange that also Khanty has the -t-in the ending: piti, payt3. This same ending can be seen also in some other Khanty colour terms, e.g. warts 'red' that is derived from war 'blood' (= Fi veri 'id.'). This is typical only for Khanty and it 
seems to be used only in some colour terms. It is possible that this suffix has referred only to colours, just like the Nganasan suffix -kuo in e.g. tusajkuo 'black' (more in Chapter 3.3.4). In Mansi there seems to be no such ending (if it is assumed that the Mansi colour term pit, piti 'black' is a loanword from Khanty), and in Hungarian this ending is very rare, especially among adjectives (Papp 1969: 107).

Theoretically, the Khanty ending (suffix?) -ts could date back to the Uralic adjectival suffix $*_{-} t A$. The last vowel is problematic, as it should have disappeared. However, according to Korhonen (1991: 70) and Kulonen (1993: 80), phonemes which carry suffixal meaning may change differently than phonemes in other positions.

\section{I.7. Nenets *pərí-}

PNen *pari- > NeT paryi (verb) 'be black', paryidye 'black', NeF piLLiće 'is black' (Lehtisalo 1956: 339-340)

= En pólzed (ползе(дь)) 'be black', polzeda, polzede 'black' (Katzschmann \& Pusztay 1978: 175)

$?<\mathrm{PS} *$ pârå- 'burn (intr.)'

In many Samoyed languages, adjectives are not a morphological class or the nature of adjectives is at least unclear (see more on adjectives in Samoyed in e.g. Szeverényi 2005). Some adjectival denotations are referred to with verbs, others with nouns. In a verb, the adjectival meaning is constructed with a participle suffix, which is a typical way of forming adjectives also in other languages such as Finnish (see e.g. Koivisto 1987). This concerns also colour terms. For instance, in Nenets the word for 'black' is a verb and the word for 'white' is a noun. One reason for such a division between word classes can be found in the etymological background.

The Samoyed languages do not have a common term for 'black'. However, the North Samoyed languages Nenets and Enets have a common term for 'black': NeT paryi (verb) 'be black'> paryidye 'black', En pólzed 'be black' > polzeda, polzede ‘black (participle)' (Lehtisalo 1956:339-340; Katzschmann \& Pusztay 1978: 175). Almost all uses of the term for 'black' seem to denote purely colour or oppositeness to 'white' as in the names for the Arctic fox in summer, париденя нохо 'black fox', and in winter, сэр" нохо 'white fox' (Tereščenko 1965: 317b, 447b).

The Tundra Nenets derivation parikku means not only black but also the genitals of a woman or a female animal (Lehtisalo 1956: 339-340). The female genitalia tend to have a negative or taboo status in various cultures. In the light of that knowledge, we may assume that the term for black would also have a negative affect, although this kind of semantic extension does not seem to occur in the other Uralic languages.

The words in both Nenets and Enets remind one greatly of the verbs meaning 'burn': NeT parā (Janhunen 1977: 114), En forabado (Katzschmann \& Pusztay 1978: 175), which date back to a Proto-Samoyed form *pârå- 'burn (intr.)' (Janhunen 
1977: 114). Phonologically the Proto-Samoyed reconstruction *pôrå- could lie behind Proto-Nenets *pari- 'be black' (the Proto-Nenets reconstruction suggested by Lotta Jalava, p.c.). The comparison is also supported by the fact that the words for 'black' in this case are verbs. Thus it is conceivable that they have developed from a verb, while the term for white, NeT ser, which is a noun, has presumably developed from a noun meaning 'ice' (Janhunen 1977: 138). Semantically this comparison is unproblematic. A semantic parallel occurs in English where the word black derives from PIE *bhleg'shine, flash, burn' (Watkins 1985: 6).

Proto-Samoyed *pârå- 'burn (intr.)' has not been linked with Proto-Uralic *pala'id.' (> Fi palaa 'burn (intr.)', SaaN buollit 'id.'), although they are semantically similar. The reason for this lack of connection is phonological, namely that PU *-l- should have changed to $*_{-j}$ - in Proto-Samoyed. However, this type of semantic and phonological similarity may be a sign that the sound changes from Proto-Uralic to ProtoSamoyed have not been fully studied.

\section{I.8. Selkup sä́a}

säkə 'black'

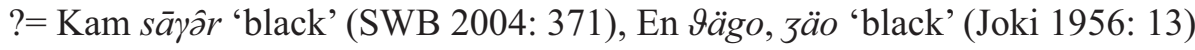

? < Ev саха, сакарйн 'black, dark' (KWB 1944: 56, SWB 2004: 371)

Donner assumed that $s \bar{a} k z$ belongs etymologically together with Kamas $s \bar{a} \gamma \hat{\partial} r$, sār 'black' (SWB 2004: 371), which has been compared to Evenki саха, сакарӣ 'black' (KWB 1944: 56b). Probably also Enets ९ägo, zäo ‘black' (Joki 1956: 13; Katzschmann \& Pusztay 1978: 186) belongs to this word group, but the etymological relations are unclear.

\section{I.9. Nganasan hejka and tusajkuo}

hejka (xeyka) ‘black' (Kortt \& Simcenko 1985: 107-108, Katzschmann 2008: 189) $\sim$ Ngan hii,hiy 'night' < PS *pi 'night' (Janhunen 1977: 123) tusajkиo (тусайкуо) 'black' (Szeverényi 2005: 86; in Katzschmann 2008: 'dark') Other forms: mусайчуса 'blacken, become black', тусайка" a 'black' (Kosterkina et al. 2001: 90)

Nganasan has two terms for 'black', heyka and tusajkuo. For instance, Szeverényi (2005: 86-87) does distinguish which is a basic colour term and which is not, although morphologically he mentions that the basic colour terms have their own marker (-kuə). If his suggestion is correct, this means that only tusajkuo would be a basic colour term. However, the word tusajkuo does not occur in all dictionaries of Nganasan, unlike heyks. In any event, I shall present both words in the following. 
Nganasan heyk does not appear to have any denotation of darkness or dirtiness, a phenomenon that seems typical for all Samoyed languages. There is, however, the following riddle (Katzschmann 2008: 58):

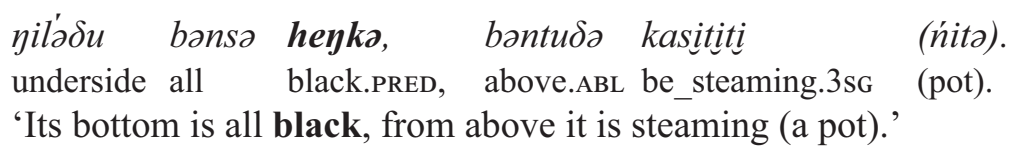

The blackness on the bottom of a kettle comes from soot, which is black. It is also dirty as it soils one's hands if one touches it. Another example is xeyka uuup $\gamma$ 'cloud', literally 'black cloud' (Sorokina \& Bolina 2001: 95). This refers to darkness (of light), or the opposite of a clear sky. It can also refer only to the dark colour of the cloud as in Finnish musta pilvi 'black cloud'.

Katzschmann (2008: 497) presents a nominal suffix $-{ }^{n} k \partial$, and gives examples

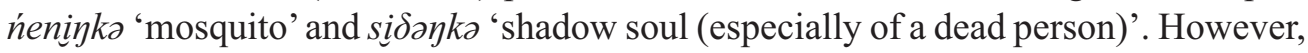
he gives no stems for these derivations, and therefore it is difficult to say, for instance, what kind of vowel shift is possible in the stem, and to what kind of stem it is possible to add the suffix. The word heyka is probably a derivation like the other examples given above, but the stem is unclear. Theoretically it might be possible to form heyka 'black' from hi 'night', which is a common Samoyed word (< PS *pi 'night', Janhunen 1977: 123). A problematic issue is that Katzschmann does not mention that the suffix ${ }^{n}-k$ could be used in derivational adjectives, and all his examples are nouns.

Katzschmann (2008: 312) mentions also another word used for black in Nganasan: tusajkuо (тусайкуо). Wagner-Nagy mentions a suffix -ckuə, -jkuə used in forming especially colour terms in Nganasan, e.g. tusajkuo 'black', tod'akuo 'yellow' (WagnerNagy 2001: 160). She notes that the stems of these colour terms are unknown.

In the texts of Katzschmann's Chrestomathie the word tusajkuo is used in the same story as heykə. Katzschmann has translated the word tusajkuo as 'dark' (Katzschmann 2008), but this division is uncertain as both tusajkuo and heyka are used as opposites to sirz" 'white' (examples are from Katzschmann 2008: 136 while the English translations are by the author):

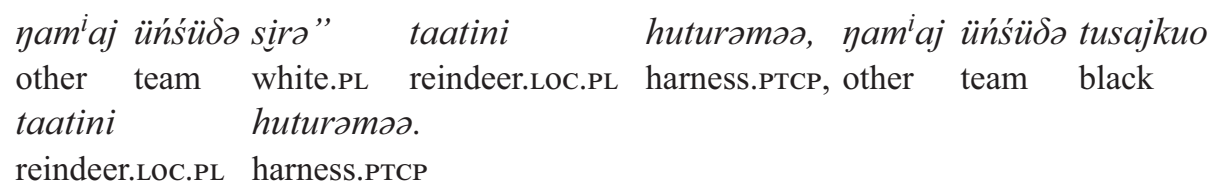

'One team (is) harnessed with white reindeer, [while] the other team (is) harnessed with dark reindeer.'

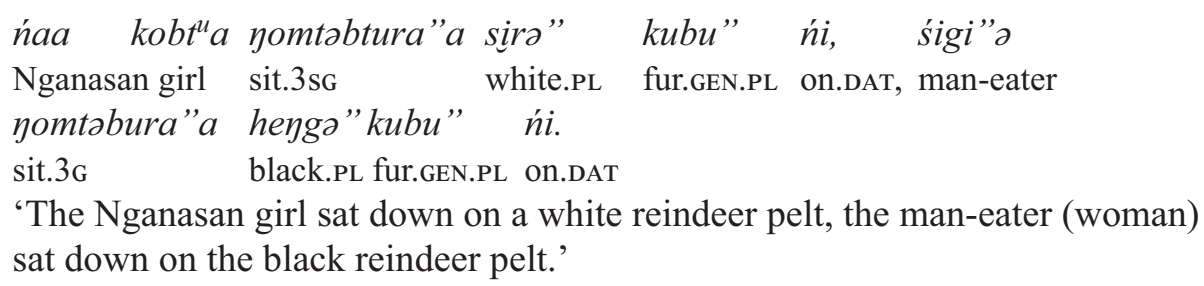


According to these examples from texts, the difference in the use of tusajkuo and heyk seems to follow the animate-inanimate opposition. In the examples from texts, hejka refers to inanimate objects. In the story of a Nganasan girl and a man-eater the word heyko is used of a reindeer pelt. The adjective tusajkuo refers always to the reindeer. In another story, the verbal form of tusajkuo (tusajtütu) is used to refer to a human being's mouth (Katzschmann 2008: 68). This might also be considered as a part of a living being, unlike the bottom of a kettle, where the word heyka is used. However, the text material is small, and thus the given assumptions may be proven wrong in later studies.

The texts from which the examples above were taken, refer to a positive-negative position between the terms for white and black. The Nganasan girl chooses white reindeer and the man-eater chooses the black/dark ones (Katzschmann 2008: 136). This suggests that the negative affect is present also in the Samoyed languages. It is not visible in the semantic extensions found in dictionaries, but becomes visible in a larger context, e.g. folk tales.

\subsection{Conclusions}

\subsection{Etymologies}

What do we hold in our hands after the analysis in the Chapter 3.1? Some old etymologies, some suggestions for new etymologies and an idea of a semantic development of the terms for 'black'.

Usually the terms for black are common to closely related languages such as Permic, Mordvin and Finnic, but the etymologies further back are more or less uncertain. A long-known etymology is that the Ugric branch has a common term for 'black', which must be considered one of the oldest known terms for black in the Uralic languages. Both Hungarian fekete and Khanty piti denote 'black' and thus also the Proto-Ugric form *pökks-tts presumably denoted 'black'. However, there are no suggested cognates outside the Ugric languages and thus the semantic background is still unclear.

Thus far, the most reliable etymology for Finnish musta has been suggested by Koivulehto (2001: 71). It is also one of the oldest etymologies presented for the terms for 'black' in the Uralic languages, as it is common to both Finnic and Saami languages. However, it is not a colour term in the Saami languages, which means that the denotation of colour has developed only in the Finnic languages. In Skolt and Inari Saami there are denotations 'darkness of colour' and 'losing its colour'. This can be the result either of an independent semantic development or Finnic influence.

In the Samoyed branch only Nenets and Enets have a common term for black: NeT paryi 'be black', En pólzed 'id'. The closest common protolanguage for Nenets and Enets is Proto-Samoyed, and therefore the Nenets and Enets terms can be reconstructed for Proto-Samoyed. In Chapter 3.1.7 I have cautiously suggested that the 
terms for 'black' in Nenets and Enets could descend from the Proto-Samoyed *para 'burn (intr.)'. The denotation of black, however, has possibly been connected with the slightly changed phonological form seen in the modern Nenets and Enets languages.

All the suggestions that combine different Uralic branches together are highly uncertain. Especially Mari šem 'black' has many suggested cognates, in Mansi, Komi, Mordvin and Finnic languages. However, all these cannot be cognates due to the phonological differences between them. Also, borrowing between Uralic languages should be considered possible in word groups of this type. The Permic śed 'black, dirty' and Finnish sonta 'muck, dung' (Wichmann 1954: 103) are a phonologically unproblematic comparison, and also semantically they seem to fit together because the feature common to these words is dirtiness. If the Mordvin ravužo, ravuža 'black' is a cognate of a Finnish rapa 'mud; mire; gravel, rubble; fragile, crispy', the semantic development would be somewhat the same as in the comparison of Permic and Finnic presented above, from 'dirty' to 'black'. This type of semantic development should be kept in mind when searching for more cognates for the terms for black in the Uralic languages.

\subsubsection{Semantic development}

In the data we see that usually the colour term has developed from some other denotation. Even the suggested loanwords are such that the borrowed word did not originally denote colour.

In Chapter 2 I suggested that the terms for black could develop from two denotations, 'dark (of light)' and 'dirty'. Surprisingly, the lack of light is not visible in any of the etymologies presented (the comparison of Nganasan henkə 'black' with ProtoSamoyed *pi 'night' is extremely hypothetical). Instead, in most cases the direction of semantic development is from 'dirty' to 'black'. This development occurs especially in the western Uralic languages: Finnic, Mordvin, Mari and Permic. In all these languages the term for black has also denotations of dirtiness.

The denotation of dirtiness is missing or at least opaque in the Saami, Ugric and Samoyed languages. These languages are quite peripheral compared to other Uralic languages. If we assume that original features are usually preserved on the periphery, the semantic development from 'dirt' to 'black' observed in Finnic, Mordvin, Mari and Permic should be regarded as an innovation.

However, the difference between central and peripheral languages and the connection between black and dirty is not without exception. An example of a possibly ongoing semantic change from dirty to black is found in Mansi where a word pāyk, paykəy has denotations 'coal, dirt; muddy, dirty', and in some dialects also 'black' (Sipöcz 1994: 54). Due to the rarity of the denotation 'black' it is probable that the other denotations are older, and the denotation has moved from 'dirty to 'black'. This semantic development supports also the suggested etymologies in other Uralic languages (especially Mordvin ravužo 'black' Fi rapa and Permic śed 'black' Fi sonta 
'muck, dung', Ma W šandô 'lavatory', E šondo 'muck, dung') which are phonologically valid but have been considered semantically problematic.

Many languages have also a denotation 'dark (of light)', but the use of it seems rather figurative and secondary, which refers to a metaphorical use instead of lexical. Koski (1983) and also Jäppinen (1999) have noted that the word for black can be used in the meaning 'dark (of light)', especially when referring to night. From referring to the darkness of night it is not a great leap to referring to the darkness of days, either concrete (Ka mussat päivät black days < one cannot see to sew) or metaphorically (Fi päiväsi mustimmat 'your blackest days' < i.e. the days of mental depression (poetic use). The semantic movement is the same with regard to the primary term for darkness in Finnish, pimeä 'dark (of light)', which presumably refers to the darkness of night, but can also refer to the darkness of day.

The studies of colour terms in other languages have suggested a development from terms denoting brightness to terms denoting hues (e.g. MacLaury 1992, Casson \& Gardner 1992, Casson 1997). Finnish musta and North Saami mosttas represent the same type of semantic development as Old English salu 'sallow' which had the brightness sense 'dark, dusky' and the hue sense 'dirty, discoloured' (Casson \& Gardner 1992: 395). Although the English sallow and its cognates do not have the denotation 'black', the denotation 'dirty' may develop into a denotation to 'black' (Harper 2001-2011). This type of semantic development is present also if Finnish hämärä 'dim' belongs together with Mari šem 'black; dirty'.

Tundra Nenets paryidye 'black' and Enets polzeda, polzede 'id.' could originate from Proto-Samoyed *para 'burn (intr.)', which is parallel to the development of the English black (< PIE * bhleg- 'burn'). Casson, however, has assumed that the meaning 'burnt, scorched' refers to hue, not brightness.

The negative aspect seems to link all the Uralic languages and thus indicates that the connection of black, dark to evil is not typical only of western culture. However, it is possible that surrounding cultures have affected the Uralic languages, e.g. the mythical aspect of the Samoyed languages, where the terms for black seem to be used in a negative sense, although the colour black does not seem to have a negative affect in everyday use. Affect could be one explanation for the vast variation in the terms for black in the Uralic languages and the relatively young age of the terms.

If we assume, like Berlin and Kay, that all languages have a term for black and also a term for white, we must accept that the colour terms change from time to time. However, the old term is not always replaced by a term borrowed from another language. Instead, a word that already exists moves to function as a colour term. The new term is taken from semantically close vocabulary. Koski (1983: 249) has assumed that Proto-Finnic * musta 'black' replaced the older term for black, *sini-, which has moved to fill the blue and possibly green area of the colour chart.

Although it is uncertain why the terms for black tend to change in languages, it seems that the semantic development is the same. The new word is taken from the same semantic field as the previous word. According to this data and the etymological suggestions, the denotation 'dirty' seems the most popular source for the new terms 
for black. It is not the only one, however. Also brightness may play a role in developing a term for black. Casson (1997) has suggested such a development for English and we can see such parallels also in some of the Uralic languages.

\section{White}

In this chapter, unlike the previous one, I shall focus on the old terms for 'white' and their denotations in the present-day languages. Terms for black tend to be either of unknown origin or the history of the words does not extend far back into the protolanguages, but there is more than one term for white reconstructed to very old protolanguages, such as the Finno-Ugric, Finno-Permic and Samoyed protolanguages. Due to the selection, the results are preliminary, but they provide clues as to what kind of semantic development the terms for white have undergone.

For the Finno-Ugric protolanguage three separate terms are reconstructed for 'white': *päje 'white; shine' (UEW: 360), *walks 'white, light, shiny; shine, light' (UEW: 554) and *ačka 'white' which is uncertain (UEW: 3). Each of these will be discussed below.

\section{I. PFU *päje 'white; shine'}

$>$ SaaN beadjut 'shine white (e.g. of someone with a white furcoat)', SaaLu päjju (attr.) 'white (of things and animals)', pä̈juk (pred.) 'white (of an animal); white reindeer', pädjat, piedjis (attr.) 'white, light', ? Hu fehér 'white' (UEW: 359360)

PFU *päjä 'fire'> SaaN baján 'thunder', ?Ko bi 'fire', ?Kha päj 'thunder'

$>$ PFU *päjwä 'fire' (derivation of *päje, Saarikivi 2010: 259) > Fi päivä 'day; sun', SaaN beaivi 'day; sun', ?? Ko bi 'fire', ?? Kha päj 'thunder', PS *pejwä 'warmth, warm'

The UEW has three separate entries that could both formally and semantically belong together: *päje 'white; shine', *päjä and *päjwä 'fire'. Both words under the reconstruction *päje are uncertain, but the present etymological dictionaries hold to this etymology (e.g. Zaicz 2006: 203). The UEW refers to the same words in Komi and Khanty in the entries for *päjä and *päjwä, and thus it is even more probable that the words are the same, although the variation in the Saami first-syllable vowel $a \sim e a$ needs a closer examination.

Proto-Samoyed *pejwä 'warmth, warm' (Janhunen 1977: 120) is not commented on in any of these articles, although it cannot be a coincidence that PFU *päjwä and PS *pejwä are so similar, both formally and semantically. Also Saarikivi (2010: 259) has noticed the similarity of these words and assumes that the form *päjwä was originally *päj(e)wä, a derivation from *päje. 


\subsection{PFU *wal's 'shine, to shine'}

> Fi vaalea 'light; blond', ? Md E valdo M valda 'light', Ko (dial.) vol'k 'bright, shining', vol'al- 'shine', Udm (dial.) val: ćcil'-val' 'shine, brightness; shining, bright', dial. also val'k, valt 'shining, bright', Man olk- 'be bright, shine', ? Hu világ 'light; world; people' (UEW: 554)

$\sim$ PFU *walks 'white, light, shiny; shine, light' (UEW: 554) > Fi valkea, valkoinen 'white; light; fire', Li vālda 'white; white cow', SaaN vielgat 'white',

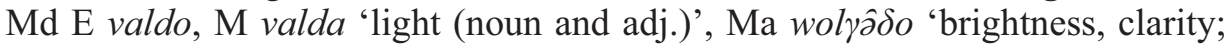
bright, clear', ? Hu világ 'light; world; people' (SSA 2000: 399, LuLpW: 1400b, Zaicz 2006: 914-915)

Another Proto-Finno-Ugric term for white in UEW (554) is *walks. In addition to 'white', the term refers also to light and brightness. In a separate entry, UEW presents the word * wal's 'shine, to shine'. It is uncertain whether the Mordvin and Hungarian forms derive from * wal' $^{\prime}$ or *walks, and therefore they are presented in both entries.

It is generally agreed that these two different reconstructions belong together. The form *walks is probably a derivation from *wals, just as Proto-Uralic * pi $\delta k \ddot{a}$ 'long' is derived from PU *pide 'long' (SSA 1995: 337). In SSA (2000: 481) North Saami vielgat has been connected with Finnish välkeä 'spacious, roomy', suggesting that the latter is only a front-vocalic form of valkea, although the denotation is rather different, as välkeä does not refer to 'white' or 'light'. It is possible that the denotation 'spacious, roomy' has developed from 'light', and this is the assumption also in SSA. The SSA connects also Finnish väleä 'quick, fast' to this word group as a variant without the velar stop - $k$-, although there is yet another semantic extension. Comparisons of this type are dangerous as both the phonological and semantic shifts would be considerably large.

Finnish vaalea 'light; blond' is phonologically exceptional because the first vowel is long. One would expect the form valea, which according to Koski (1983: 55 ) occurs in some Finnish dialects. Other forms with a short vowel are e.g. Fi valeva 'light, pale' and Est valev 'light, shiny'. According to Koski (ibid.), the original form vale- entered into a quantitative variation in the Finnic languages and thus the form vaalea has emerged.

PFU *wal'- is a colour term only in the Finnic and Saami languages. In all other languages it still means mostly light. In the Finnic branch also the denotation 'light' has been preserved in the noun Fi valo, Est valu 'light'. In Finnish the form valkea is also a noun denoting 'fire'. Koski assumes that the colour term emerged in ProtoFinnic, although SaaN vielgat is also a basic colour term. 


\subsection{PFU *ačka 'white'}

> Fi hahkea, haahkea, dial. ahka 'grey', ? ha(a)hka 'common eider (Somateria mollissima)', Ka hoahka 'grey (wool)', Ve hahk 'grey', hahkoi 'grey sheep' | Est hahk 'grey', ? ahk 'eider (Somateria mollissima)' | Li $\vec{\jmath}$ gi, $\vec{a}$ gi (<*hahkainen) 'grey', mdE ašo, M akša 'white; clean', Ma oša, oš 'white, blond; clean', ? KhaS aš, äš '(white) clay; chalk' (UEW: 3; SSA 1992: 124)

$\sim$ PFP *'ćäckä 'clean, white; shine clean, white'> ? SaaLu tjäskāk (pred.), tjieskis (attr.) 'sharp, stinging', tjieskis-päjuk 'snow-white reindeer; iris white' (LuLpW: 1162, 1221), SaaN čeaská- 'look snow-white, shine white', čeaskat 'quite white, pure white, snow-white', SaaIn čeaskađ̆ 'snow-white (of reindeer, of clothes that are made of reindeer pelt, of ermine)', Ko ćoćkom 'white, clean' (UEW: 611).

The PFU word *acka 'white' is the only non-Ugric term that is a colour term in all other languages except Khanty, which is uncertain due to semantic differences. The SSA (1992: 124) connects Finnish hahkea, haahkea 'grey' with ha(a)hka 'eider' (Est ahk 'id.'). Koski (1983: 59) is uncertain about whether the denotation 'eider' is etymologically the same as the words referring to colour. Instead, he suggests that the animal name could be onomatopoeic, based on the sounds that eiders make (Koski 1983: 339).

Unlike the other Finno-Ugric terms for white, this one does not include the meaning 'bright', but it does include the meaning 'clean', which is typical also for the Finnic-Permic word *'ćäck $\ddot{a}$ 'clean, white; shine clean, white'. It seems to be a frontvocalic variant of *acka with an initial affricate. In fact, the initial affricate could also explain the $h$-in most Finnic cognates. There is even more reason to assume that these two words are cognates as we look at the areal distribution, which is complementary, for according to the UEW, the cognates of PFU *ačka and PFP *ćäčä do not occur in the same languages. This might be a parallel to the assumption that North Saami vielgat 'white' is a front-vocalic variant of Finnish valkea 'white'.

Lule Saami tjäskāk, (attr.) tjieskis 'sharp, stinging' has not been connected to SaaN čeaskat before. Probably the reason has been semantical, as it is very different from the other Saami words. However, Grundström (LuLpW: 1162) presents also a compound tjieskis-päjjuk 'snow-white reindeer; iris white' which has exactly the same semantic aspect as North Saami čeaskat 'quite white, pure white, snow white' and Inari Saami čeaskad 'snow-white'. It is possible that tjäskāk, (attr.) tjieskis includes two homonyms, and only the form in tjieskis-päjjuk would belong together with SaaNčeaskat and SaaIn čeaskađ. However, it is not obligatory to assume homonymy in this type of semantic difference. It is also possible that in Lule Saami snowwhite has taken on a negative aspect, as shining snow stings the eye. Also in the other Saami languages the denotation is 'pure white' and 'snow-white'. Here, the assumed development would be from 'pure white' to 'whiteness stinging the eye' in Lule Saami.

For the Saami words one can see the prototypical white or snow in translations. Etymologically they do not come from a word meaning snow, and this might also be 
just a translational aspect. When one asks an informant to explain a kind of white, the informant might compare the whiteness to snow, i.e. as white as can be. Snow is also a prototypical white entity in the north.

Semantically the words *ačka and *cäčkä both have the definition 'clean' instead of 'bright', which is a denotation that the other Finno-Ugric terms (*päje, *wals') have. Based on the material presented, we may assume that brightness and cleanliness were separate categories at least in Proto-Finno-Ugric and perhaps earlier. The term for white can develop from both categories, but the denotations 'clean' and 'bright' do not seem to overlap.

\subsection{PSam *ser 'white'}

> Ngan сыр, NeT сэр”, сэрако 'white', Selk serr 'white', Kam sịr (Janhunen 1977: 138)

$<$ PSam *ser 'ice' (Janhunen 1977: 138)

While the Samoyed languages lack a common term for 'black', they do have a common term for 'white': PSam *ser (Janhunen 1977: 138). Samoyed *ser 'white' is probably etymologically identical to *ser 'ice'. Janhunen presents these two words in separate entries, but compares them (ibid.). In Lehtisalo's Juraksamojedisches Wörterbuch (1956: 410) the descendants of these two words are discussed in the same entry. Jäppinen (1999) assumes that snow is a prototypical white entity. While this is true, etymologically this Samoyed *ser is the only word in this set of data that would come from something that evokes snow.

\subsection{Conclusion}

Many terms for white presented in the UEW are phonologically so similar to each other that eventually only three different terms for white can be seen: *päje (or *päjä), *wal's (possibly also ? *wäl's, according to Fi väleä 'quick, fast', välkeä 'spacious, roomy' and SaaN vielgat 'white') and *ačka (or *ćäčkä). Possibly none of these words denoted 'white' in the protolanguage, as the colour term occurs only in some branches of the family. The word *päje is the best candidate for originally meaning 'white', as the suggested derivates denoting white are found in the Saami languages and Hungarian. In Hungarian the derivate fehér is a basic colour term.

Not all words denoting 'bright' developed into 'white' or any other colour term. Proto-Uralic had a word *jelä 'light; sun; day' (> SaaN jalahas, jealahas 'complete cloudlessness', KhaN jil 'cardinal point, point of the compass', NeT яля 'day; bright, clear; light (adj.)') (UEW: 96). The development from 'light' to 'white' could be expected, but in this case a term for 'white' has not emerged.

The Finno-Ugric terms for white display a division between cleanliness and brightness. The denotation 'white' can develop both from 'cleanliness' and 'bright- 
ness', but it seems that brightness and cleanliness themselves are separate semantic categories. The old terms include also the denotation 'warm', and all this indicates that the brightness category refers to fire and to the sun that are bright and warm, and red and yellow. In the studies of colour terms after Berlin and Kay's theory (e.g. Croft 2003: 279) it has been noted that the term for white includes also warm colours (red, yellow, orange). Warmth is visible also in the Finno-Ugric terms for white, but etymologically the focus in the colour has stayed on white.

\section{Discussion}

In this study we have not identified Proto-Uralic terms for black and white. However, we have seen what semantic types lurk behind the colour terms of present languages, especially concerning the terms for black. The hypothesis presented in Chapter 2 also needs modifying.

Many studies of colour categories are synchronic, and the whole theory concerning the evolution of the system of colour terms in a language is based on synchronic studies. However, etymological studies show that, like many other words in language, colour terms change. They are borrowed, or new words are derived from a stem that already exists in the language. It is also possible that a word expands its meaning to another semantic field. Usually the semantic extension moves from concrete to abstract. This is typical especially for adjectives.

In the data we find that the motivations for naming black are restricted to a few possibilities. Dirt and murkiness are the most frequent motivations to expand meaning to black. Also 'burning' can be a motivation in naming black not only in the IndoEuropean languages but in Uralic as well.

Surprisingly, dark (of light) and night are not used as motivations for naming the colour black. In Nganasan, the connection between hii 'night' and heyka 'black' is highly uncertain.

The terms for white come from light and fire, which support the notion that the term for white could refer also to warm colours like red and yellow. Also cleanliness and purity can develop a denotation of white. However, the denotation 'bright' does not seem to occur together with 'clean'. It is probable that the denotations 'bright' and 'clean' have a common feature, 'white', but the categories 'bright' and 'clean' do not overlap.

Many of the Uralic languages tend to have a separate suffix for colours. It has been suggested that Mordvin E -žo, M -ža have developed to a colour suffix by analogy with words like MdE piže 'yellow' and ožo 'green'. In Khanty a suffix -ts occurs

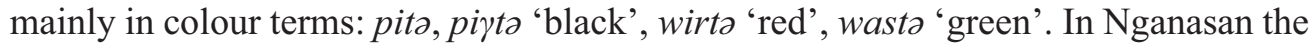
suffix - kuo has been seen as a colour term suffix: tusajkuo 'black', dabakuo 'red'. It seems that it has been important to distinguish colour terms from other words, especially adjectives.

As can be seen from the data presented in Chapter 3, the etymological difference between terms for 'black' and 'white' is in their dating. The terms for 'black' 
cannot be reconstructed very far back in the protolanguage. Some etymologies suggest that the terms for black are either borrowed from neighbouring languages or still of unknown origin. However, the borrowings are not very recent, and e.g. Russian чёрный 'black' does not lie behind any Uralic terms. Unlike black, the semantic field of white has more than one term reconstructed for the Finno-Ugric protolanguage. Also Proto-Samoyed had a term for white, although it is impossible to reconstruct a common term for black in the Samoyed languages.

Another difference between black and white is affect. As in many other languages, also in the Uralic languages the terms for black have a negative affect. In Saami, where the terms for black do not denote dirtiness or darkness, the connotation is negative. The negative aspect can be seen in Inari Saami čappadas 'devil', but also in the Saami idea of emptiness and invisibility behind the word čáhppat 'black'. The negative aspect is visible also in the Samoyed languages, although otherwise additional meanings are difficult to find. The negativity lies more in the context where the words are used than in the word itself.

The negative affect could be one reason for the vast variation of the terms for 'black' in the Uralic languages. The meaning 'light, pure, white' has probably always had a positive affect and this may have preserved the old terms. The meaning 'black' has had or taken on a negative affect, and thus it has a kind of "taboo" status, which leads to a need to alter or even change the word from time to time (for affect see e.g. Kulonen 2006).

In English the word dark denotes both darkness of colour and lack of light. The Uralic data presents denotations of the lack of light, but it seems secondary due to its metaphorical nature. The denotation 'dark (of light)' is missing also in the etymologies presented. However, the etymologies of the Finno-Ugric terms for 'white' include denotations to both light and cleanliness. The development from the semantic categories bright-dark and clean-dirty is presented in Figure 5.

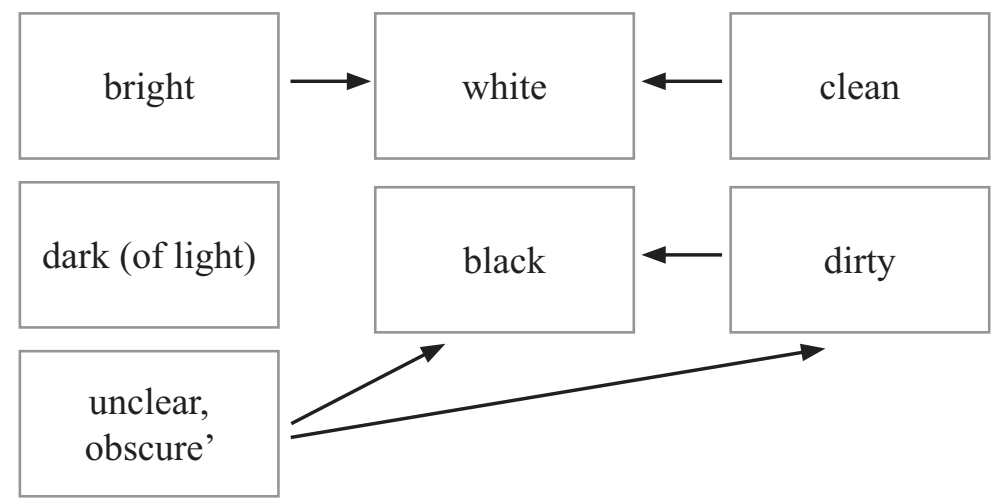

Figure 5. The directions of semantic development of the terms denoting 'white' and 'black'.

The denotations 'bright' and 'clean' may both develop a term for white, but they do not seem to overlap, as the denotation connecting these two features is 'white'. The results concerning the terms for white are preliminary because the data is restricted 
to old terms. Concerning the colour term 'black' the semantic development is not that simple. In chapter two I assumed that the denotations 'dirty' and 'dark (of light)' could develop into a term for black. However, it seems that of the two only 'dirty' motivates the semantic development to 'black'. Uralic *pil'mз- 'dark (of light)' and Finno-Ugric *kums- 'cloud' do not lie behind any of the terms for black studied above. Neither do they have the denotation 'black' or even 'dark (of colour)' in any of the languages where they still exist. Both of the words have actually remained salient because all the derivates of both words have preserved their original denotation. Uralic *pilms has remained purely a brightness term, and it does not seem to interfere with colours at all because there are no languages where it would denote the darkness of colour. Instead, in many Uralic languages the terms for black refer also to dark shades of colour.

Murkiness and obscurity seem to be one semantic source that can develop into a term for black. According to Casson's example of English sallow as well as the data presented for Finnic and etymological suggestions of the cognates of Mari šem(e) 'black', the obscurity would refer to brightness (see Chapter 3.2.2). However, the English and Finnic examples suggest a connection between obscurity and dirtiness (which, according to Casson, refers to hue), and it is still unclear if the denotation 'dirty' is needed between the denotations 'obscure' and 'black' or if obscurity can develop directly into a denotation 'black'.

Casson (1997) assumes that especially the terms for black and white were primary brightness terms in Old English. For instance, the term black in Old English denoted primarily brightness, but had some sense of hue, 'burned, scorched'. This type of semantic development seems also possible in the Uralic languages, if the suggested etymology of the Nenets and Enets colour terms in Chapter 3.2.3 is correct.

In the future, the words denoting darkness of colour and darkness of light in the Uralic languages should be more thoroughly studied, taking into account the context in which they appear. One problem to solve is whether the Uralic languages normally display different words denoting darkness of light and darkness of colour. The findings could be compared with data from other languages, especially those like English, German and Swedish which have words such as dark, dunkel and mörk denoting both darkness of light and of colour.

\section{Abbreviations}

\section{Glosses}

$\begin{array}{ll}2 & \text { second person } \\ 3 & \text { third person } \\ \text { ABL } & \text { ablative } \\ \text { DEF } & \text { definite } \\ \text { ELA } & \text { elative } \\ \text { GEN } & \text { genitive } \\ \text { LOC } & \text { locative } \\ \text { NEG } & \text { negative } \\ \text { IMP } & \text { imperative }\end{array}$

$\begin{array}{ll}\text { INF } & \text { infinitive } \\ \text { PL } & \text { plural } \\ \text { PRED } & \text { predicative } \\ \text { PRS } & \text { present } \\ \text { PRT } & \text { particle } \\ \text { PTCP } & \text { participle } \\ \text { SG } & \text { singular } \\ \text { VN } & \text { verbal noun }\end{array}$




\section{Languages and dialects}

$\begin{array}{llll}\text { En Enets } & \text { NeT } & \text { Tundra Nenets } \\ \text { Eng } & \text { English } & \text { Ngan } & \text { Nganasan } \\ \text { Est } & \text { Estonian } & \text { Nr } & \text { Norwegian } \\ \text { EstS } & \text { South Estonian } & \text { PFi } & \text { Proto-Finnic } \\ \text { Ev } & \text { Evenki } & \text { PFP } & \text { Proto-Finno-Permic } \\ \text { Fi } & \text { Finnish } & \text { PFU } & \text { Proto-Finno-Ugric } \\ \text { Germ } & \text { German } & \text { PGerm } & \text { Proto-Germanic } \\ \text { Hu Hungarian } & \text { PIE } & \text { Proto-Indo-European } \\ \text { Icel Icelandic } & \text { PMa } & \text { Proto-Mari } \\ \text { Ing Ingrian } & \text { PMd } & \text { Proto-Mordvin } \\ \text { Ka Karelian } & \text { PNen } & \text { Proto-Nenets } \\ \text { Kam Kamas } & \text { PPerm } & \text { Proto-Permic } \\ \text { Kha Khanty } & \text { PSaa } & \text { Proto-Saamic } \\ \text { KhaN North Khanty } & \text { PSam } & \text { Proto-Samoyed } \\ \text { Ko Komi } & \text { PU } & \text { Proto-Uralic } \\ \text { KoUd Udora dialect } & \text { PUg } & \text { Proto-Ugric } \\ \text { Li } & \text { Livonian } & \text { SaaIn } & \text { Inari Saami } \\ \text { Lu Lude } & \text { SaaKld } & \text { Kildin Saami } \\ \text { MaH } & \text { Hill Mari } & \text { SaaLu } & \text { Lule Saami } \\ \text { MaM Meadow Mari } & \text { SaaN } & \text { North Saami } \\ \text { Man Mansi } & \text { SaaPi } & \text { Pite Saami } \\ \text { ManE Eastern Mansi } & \text { SaaS } & \text { South Saami } \\ \text { ManN North Mansi } & \text { SaaSko } & \text { Skolt Saami } \\ \text { ManS South Mansi } & \text { Selk } & \text { Selkup } \\ \text { ManW Western Mansi } & \text { Swiz } & \text { Swiss German } \\ \text { Md Mordvin } & \text { Udm } & \text { Udmurt } \\ \text { MdE Erzya Mordvin } & \text { Ve } & \text { Veps } \\ \text { MdM Moksha Mordvin } & \text { Vo } & \text { Vote } \\ \text { NeF Forest Nenets } & & \\ \end{array}$

\section{References}

Aikio, Ante 2009: The Saami loanwords in Finnish and Karelian. Academic dissertation, the Faculty of Humanities of the University of Oulu. $-<$ http://cc.oulu.fi/ anaikio/slw.pdf $>$ 4.10.2011

Bartens, Raija 1999: Mordvalaiskielten rakenne ja kehitys. Suomalais-Ugrilaisen Seuran Toimituksia 232. Helsinki: Suomalais-Ugrilainen Seura.

Bergsland, Knut \& Magga, Lajla Mattsson 1993: Aarjelsaemien-daaroen baakogaerjal Sydsamisk-norsk ordbok. Alta.

Berlin, Brent \& Kay, Paul 1969: Basic color terms: their universality and evolution. Berkeley: University of California Press.

Berlin, Brent \& Kay, Paul \& Merrifield, William 1991: Biocultural implications of Systems of Color Naming. - Journal of Linguistic Anthropology vol. 1: 12-25.

Casson, Ronald W. 1997: Color shift: evolution of English color terms from brightness to hue. - C. L. Hardin \& Luisa Maffi (eds), Color categories in thought and language. Cambridge: Cambridge University Press: 224-239.

Casson, Ronald W. \& Gardner, Peter M. 1992: On brightness and color categories: Additional data. - Current anthropology 33: 395-399. 
Croft, William 2003: Typology and Universals. Second Edition. Cambridge: Cambridge University Press.

Csúcs, Sándor 2005: Die Rekonstruktion der permischen Grundsprache. Budapest: Akadémiai Kiadó.

DEWOS = Steiniz, Wolfgang 1966-1993: Dialektologisches und etymologisches Wörterbuch der ostjakischen Sprache. Berlin: Akademie Verlag.

Futaky, István 1981: Zur herausbildung des farbfeldes im Finnougrischen. - Lakó-emlékkönyv Nyelvészeti tanulmányok. Budapest: ELTE: 48-58

Hallap, Valmen 1983: Eesti ja sugulaskeelte adjektiivitüüpe. - Keel ja kirjandus 26: 422-432.

Harper, Douglas 2001-2011: Online Etymology Dictionary. $-<$ http://www.etymonline.com> 8.11.2011

Honti, László 1986: A vogul $s$ és š U/FU alapnyelvi szibiláns előzményei - Nyelvtudományi Közlemények 88: 258-263.

Häkkinen, Kaisa 2004: Nykysuomen etymologinen sanakirja. Juva: WSOY.

Idström, Anna \& Morottaja, Hans 2006: Inarinsaamen idiomisanakirja. Inari: Sámitigge.

InLpW = Itkonen, Erkki 1986-1989: Inarilappisches Wörterbuch I-IV. Unter mitarbeit von Raija Bartens und Lea Laitinen. Lexica Societatis Fenno-Ugricae XX. Helsinki: Suomalais-Ugrilainen Seura.

Itkonen, Erkki 1953: Zur geschichte des vokalismus der ersten silbe im tscheremissischen und in den permischen Sprachen.-Finnisch-ugrische Forschungen 31: 149-345.

Itkonen, T. I. 1958: Koltan- ja kuolanlapin sanakirja = Wörterbuch des Kolta- und Kolalappischen. Lexica Societatis Fenno-Ugricae 15. Helsinki: Suomalais-Ugrilainen Seura.

Janhunen, Juha 1977: Samojedischer Wortschatz: gemeinsamojedische Etymologien. Castrenianumin toimitteita 17. Helsinki: Helsingin yliopisto \& Suomalais-Ugrilainen Seura.

Janhunen, Juha 1981: Uralilaisen kantakielen sanastosta. - Journal de la Société FinnoOugrienne 77: 219-271. Helsinki: Suomalais-Ugrilainen Seura.

Jäppinen, Ulla 1999: Kielen ja ajatusten kliseet. Värien nimitysten käyttö eräissä suomenkielisissä idealistissävyisissä teksteissä. Åbo: Åbo Akademi University Press.

Joki, Aulis J. 1956: Kleinere Wörterverzeichnisse Jurak- Jenissei- und Tawgisamojedischen, Katschatatarischen und Tungusischen. - Journal de la Société Finno-Ougrienne 58: 1-27.

Katzschmann, Michael: Chrestomathia Nganasanica : Texte - Übersetzung - Glossar - Grammatik. Bearbeitung der Нганасанская фольклорная хрестоматия zusammengestellt von Kazis I. Labanauskas unter Berücksichtigung des Словарь нганасанско-русский и русско-нганасанский. Norderstedt Nganasanica; 1. Göttingen: M. Katzschmann.

Katzschmann, Michael \& Pusztay, János 1978: Jenissej-samojedisches (enzisches) Wörterverzeichnis. Fenno-Ugrica 5. Hamburg: Buske.

KKS = Virtaranta, Pertti \& Koponen, Raija (eds) 1968-2005: Karjalan kielen sanakirja 1-6. Lexica Societatis Fenno-Ugricae. Helsinki: Suomalais-Ugrilainen Seura.

Koivisto, Helinä 1987: Partisiippien adjektiivistuminen suomen kielessä. Helsinki: Suomalaisen Kirjallisuuden Seura.

Koivulehto, Jorma 1997: Were the Baltic Finns "clubmen"? On the etymology of some ancient ethnonyms. - Ritva Liisa Pitkänen \& Kaija Mallat (eds): You name it. Perspectives on onomastic research: 151-169. Studia Fennistica Linguistica 7. Helsinki: Suomalaisen Kirjallisuuden Seura.

Koivulehto, Jorma 1998: Puhdas ja Suomi. - Virittäjä 102: 425-434.

Koivulehto, Jorma 2001: Etymologie und lehnwortforschung ein Überblick um 2000. - Finnisch-Ugrische Forschungen 56: 42-78.

Koponen, Eino 1998: Itämerensuomalaisten kielten meterologisen sanaston etymologiaa Lauri Hakulisen väitöskirjan aineiston valossa. - Virittäjä 102: 506-530. 
Koponen, Eino 2009: Unohdettuja ja uusia etymologioita. Presentation in the Finno-Ugrian Society 20.2.2009. Handout.

Korhonen, Mikko 1991: Remarks on the structure and history of the uralic case system. Journal de la Société Finno-Ougrienne 83: 163-180.

Kortt, I. R. \& Simcenko, Ju. B. 1985: Wörterverzeichnis der Nganasanischen Sprache. Berlin: Systemata Mundi.

Koski, Mauno 1983: Värien nimitykset Suomessa ja lähisukukielissä. Suomalaisen Kirjallisuuden Seuran Toimituksia 391. Helsinki: Suomalaisen Kirjallisuuden Seura.

Kosterkina 2001 = Костеркина, Н. Т. \& Момде, А. Ч. \& Жданова Т. Ю.: Словарь нганасанско-русский и русско-нганасанский. Санкт-Петербург: Просвещение.

KT $=$ Karjalainen, K. F. \& Toivonen, Y. H. 1948: Ostjakisches Wörterbuch. Lexica Societatis Fenno-Ugricae X. I-II. Helsinki: Suomalais-Ugrilainen Seura.

Kulonen, Ulla-Maija 1993: Johdatus unkarin kielen historiaan. Suomi 170. Helsinki: Suomalaisen Kirjallisuuden Seura.

Kulonen, Ulla-Maija 2006: Eläimet ja affekti - etymologisia huomioita. Virittäjä 110: 322-334.

Кuruč = Куруч, М. Р. 1985: Caамсkо - Pуссkий словарь. Мосkва.

KWB = Donner, Kai \& Joki, Aulis Johannes 1944: Kai Donners Kamassisches Wörterbuch nebst Sprachproben und Hauptzügen der Grammatik. Lexica Societatis Fenno-Ugricae 8. Helsinki: Suomalais-Ugrilainen Seura.

Lagercrantz, Eliel 1939: Lappischer Wortschatz. I-II. Lexica Societatis Fenno-Ugricae 6. Helsinki: Suomalais-Ugrilainen Seura.

Lappalainen, Marja 1991: Perusvärinnimitykset saamessa. A Master's Thesis in the FinnoUgrian studies. University of Helsinki.

Lehtiranta, Juhani 1989: Yhteissaamelainen sanasto. Suomalais-Ugrilaisen Seuran Toimituksia 200. Helsinki: Suomalais-Ugrilainen Seura.

Lehtisalo, Toivo 1956: Juraksamojedisches Wörterbuch. Lexica Societatis Fenno-Ugricae 13. Helsinki: Suomalais-Ugrilainen Seura.

Levinson, Stephen C. 2000: Yélî Dnye and the Theory of Basic Color Terms. - Journal of Linguistic Anthropology 10 (1): 3-55.

LpWsch = Lagecrantz, Eliel 1939: Lappischer Wortschatz. Lexica Societatis Fenno-Ugricae 6. Helsinki: Suomalais-Ugrilainen Seura.

Lucy, John A. 1997: The linguistics of "color". - Clyde L. Hardin \& Luisa Maffi, Color Categories in Thought and Language. Cambridge: Cambridge University Press. 320-346.

LuLpW = Grundström, Harald 1946-1954: Lulelapsk ordbok. Skrifter utgivna genom Landsmåls- och folkminnesarkivet i Uppsala. 1. Uppsala: A.-B. Lundequitiska bokhandeln.

Lyons, John 1999: The Vocabulary of Colour with Particular Reference to Ancient Greek And Classical Latin. - Alexander Borg (ed.), The Language of Color in the Mediterranean: An Anthology on Linguistic and Ethnographic Aspects of Color Terms. Stockholm: Almqvist and Wiksell. 38-75.

Lytkin $1970=$ Лыткин, В. И. \& Гуляев, Е. С. 1970: Краткий этимологический словарь коми языка. Сыктывкар: Коми книжное издательство.

MacLaury, Robert E. 1992: From Brightness To Hue - An Explanatory Model Of ColorCategory Evolution. - Current anthropology 33: 137-186.

MdWb = Paasonen, Heikki 1990-1996: Mordwinisches Wörterbuch I-IV. Lexica Societatis Fenno-Ugricae XXIII. Kotimaisten kielten tutkimuskeskuksen julkaisuja 59. Helsinki: Suomalais-Ugrilainen Seura - Kotimaisten kielten tutkimuskeskus - Venäjän tiedeakatemian kielitieteen laitos.

Merriam-Webster 1986 = Webster's School Dictionary. Springfields, Massachusetts: Merriam-Webster Inc. 
Munkácsi, Bernát \& Kálmán, Béla 1986: Wogulisches Wörterbuch. Budapest: Akadémiai Kiadó.

Nielsen, Konrad 1932/1936/1938: Lappisk ordbok / The Lapp Dictionary 1-3. Oslo: H. Aschehoug \& Co.

Oja, Vilja 1999: Estonian Adjectives Denoting the Darkness of Colours. - Linguistica Uralica 35: 193-204.

Ojanen, Muusa 1985: Adjektiivikategoria venäläis-lyydiläisissä kontakteissa. Lingvistinen interferenssitutkimus. Suomalais-Ugrilaisen Seuran Toimituksia 188. Helsinki: Suomalais-Ugrilainen Seura.

Paasonen, Heikki \& Donner, Kai 1926: H. Paasonens ostjakisches Wörterbuch nach den Dialekten an der Konda und am Jugan. Lexica Societatis Fenno-Ugricae 2. Helsinki: Suomalais-Ugrilainen Seura.

Parviainen, Johanna 2010: Valkoinen läiskä kartalla. Perusvärinnimet ja niiden merkityskentät unkarin- ja suomenkielisissä idiomeissa. Master's Thesis in the Hungarian studies and Finnish. University of Helsinki. - <http://urn.fi/URN:NBN:fi-fe201101131042> 5.10.2011

Rahkonen, Pauli 2009: The Linguistic Background of the Ancient Meshchera Tribe and Principal Areas of Settlement. - Finnisch-Ugrische Forschungen 60: 160-200.

Rédei, Károly 1970: Die syrjänischen Lehnwörter im Wogulischen. Budapest: Akadémiai Kiadó.

Regier, Terry \& Kay, Paul \& Khetarpal, Naveen 2009: Color naming and the shape of color space. - Language 85: 884-892.

Saarikivi, Janne 2006: Vanhoja etymologioita uusissa kansissa. - Virittäjä 110: 111-123

Saarikivi, Janne 2010: Ystävästä, uskosta ja vokaaleista. - Sirkka Saarinen \& Kirsti Siitonen \& Tanja Vaittinen (eds), Sanoista kirjakieliin: juhlakirja Kaisa Häkkiselle 17. marraskuuta 2010: 249-263. Suomalais-Ugrilaisen Seuran Toimituksia. Helsinki: Suomalais-Ugrilainen Seura.

Sammallahti, Pekka 1989: Saamelais-suomalainen sanakirja. Ohcejohka: Jorgaleaddji Oy.

Sammallahti, Pekka 1999: Saamen kielen ja saamelaisten alkuperästä. - Paul Fogelberg (ed.), Pohjan poluilla. Suomalaisten juuret nykytutkimuksen mukaan. Bidrag till kännedom av Finlands natur och folk 153. Helsinki: Societas Scientiarum Fennica. 70-90.

Saukkonen, Pauli \& Haipus, Marjatta \& Niemikorpi, Antero \& Sulkala, Helena 1979: Suomen kielen taajuussanasto $=$ A Frequence Dictionary of Finnish. Helsinki: WSOY.

Serebrennikov 1967 = Серебренников В. А: Историческая морфология мордовских языков. Москва.

Setälä, E. N. 1899: Yhteissuomalainen äännehistoria. 1. ja 2. vihko. Helsinki: Suomalaisen Kirjallisuuden Seura.

Shields, Kenneth Jr. 1979: Indo-European basic colour terms. - The Canadian Journal of Linguistics 24: 142-146.

Sipöcz, Katalin 1994: A vogul nyelv színnevei. Studia Uralo-Altaica, supplementum 3. Szeged: Universitas Szegediensis.

SKES = Toivonen, Y. H. \& Itkonen, Erkki \& Joki, Aulis J. \& Peltola, Reino (eds) 1955-1978: Suomen kielen etymologinen sanakirja 1-6. Lexica Societatis Fenno-Ugricae XII. Helsinki: Suomalais-Ugrilainen Seura.

Sorokina \& Bolina 2001 = Сорокина И. \& Болина, Д. 2001: Энецко-русский и русскоэнеикий словарь. Ст. Петербург: Просвещение.

SSA = Itkonen, Erkki \& Ulla-Maija Kulonen (eds) 1992-2000: Suomen sanojen alkuperä. Etymologinen sanakirja. Suomalaisen Kirjallisuuden Seuran Toimituksia 556, Kotimaisten kielten tutkimuskeskuksen julkaisuja 62. Helsinki: Kotimaisten kielten tutkimuskeskus - Suomalaisen Kirjallisuuden Seura. 
Sutrop, Urmas 1995: Eesti keele põhivärvinimed. - Keel ja kirjandus 12: 797-808. Sutrop, Urmas 2000: The Basic Colour Terms in Estonian. - Trames 4 (1): 143-168.

SWB = Donner, Kai \& Sirelius, U. T. \& Alatalo, Jorma 2004: Sölkupisches Wörterbuch. Aus Aufzeichnungen von Kai Donner, U. T. Sirelius und Jarmo Alatalo. Lexica Societatis Fenno-Ugricae 30. Helsinki: Suomalais-Ugrilainen Seura.

Szeverényi, Sándor 2005: Lexical categorization of property concept words in the Samoyedic languages. - Wagner-Nagy, Beáta (ed.), Mikola-konferencia 2004. Szeged: SzTE Finnugor Tanszék. 75-93.

Taylor, John R. 1991: Linguistic categorization: prototypes in linguistic theory. Oxford: Oxford University Press.

Tereščenko = Терещенко, Н. М. 1965: Ненецко-русский словаь. Москва: Советская Энциклопедия.

TschWB $=$ Moisio, Arto \& Saarinen, Sirkka \& Porkka, Volmari \& Genetz, Arvid - Wichmann, Yrjö \& Räsänen, Martti \& Uotila, T. E. \& Itkonen, Erkki (eds) 2008: Tscheremissisches Wörterbuch. Lexica Societatis Fenno-Ugricae 32. Kotimaisten kielten tutkimuskeskuksen julkaisuja 151. Helsinki: Suomalais-Ugrilainen Seura - Kotimaisten kielten tutkimuskeskus.

Turunen, Rigina 2002: Die farbbezeichnungen im mokscha-mordwinischen. - FinnischUgrische Forschungen 57: 167-194.

UEW = Rédei, Karoly 1988-1991: Uralisches etymologisches Wörterbuch I-III. Wiesbaden: Otto Harrassowitz.

Uusküla, Mari 2008: Basic colour terms in Finno-Ugric and Slavonic languages: myths and facts. Tartu: Tartu University Press.

Wagner-Nagy, Beáta Boglárka 2001: Die Wortbildnung im Nganasanischen. Studia UraloAltaica 43. Szeged: Universitas Szegediensis.

Watkins, C. (ed.) 1985: The American Heritage Dictionary of Indo-European Roots. Boston: Houghton Mifflin.

Wichmann, Yrjö 1954: Wotjakische Chrestomathie mit Glossar. Apuneuvoja suomalaisugrilaisten kielten opintoja varten 2. Helsinki: Suomalais-Ugrilainen Seura.

Wichmann, Yrjö 1987: Wotjakischer Wortschatz. Aufgezeichnet von Yrjö Wichmann. Bearbeitet von T. E. Uotila und Mikko Korhonen. Herausgegeben von Mikko Korhonen. Lexica Societatis Fenno-Ugricae XXI. Helsinki: Suomalais-Ugrilainen Seura.

Wichmann, Yrjö \& Uotila, T. E. 1942: Syrjänischer Wortschatz nebst Hauptzügen der Formenlehre. Lexica Societatis Fenno-Ugricae 7. Helsinki: Suomalais-Ugrilainen Seura.

Wierzbicka, Anna 2008: Why there are no 'colour universals' in language and thought. Journal of the Royal Anthropological Institute 14: 407-425.

Wiklund, K. B. 1894: Kleine lappische Chrestomathie mit Glossar. Apuneuvoja suomalaisugrilaisten kielten opintoja varten $=$ Hilfsmittel für das Studium der finnisch-ugrischen Sprachen I. Helsingfors: Suomalais-Ugrilainen Seura.

Zaicz, Gábor 2006: Etimológiai szótár. Magyar szavak és toldalékok eredete. 1. kiadás p. A magyar nyelv kézikönyvei; 12. Budapest: Tinta.

Zajceva, Marija \& Mullonen, Marija 1972 = Зайцева, М. И. \& Муллонен, М. И.: Словарь вепсского язика. Ленинград.

Zaiceva, Nina 2010: Uz'vepsä-venälaine vajehnik. Petroskoi: "Periodika".

Ilona Rauhala <ilona.rauhala@helsinki.fi> 